\title{
Effectiveness of replacing catalytic converters in LPG-fueled vehicles in Hong Kong
}

\author{
Xiaopu Lyu ${ }^{1}$, Hai Guo ${ }^{1}$, Isobel J. Simpson ${ }^{2}$, Simone Meinardi ${ }^{2}$, Peter K. K. Louie ${ }^{3}$, Zhenhao Ling ${ }^{4}$, Yu Wang ${ }^{1}$, \\ Ming Liu ${ }^{1}$, Connie W. Y. Luk ${ }^{3}$, Nan Wang ${ }^{5}$, and Donald R. Blake ${ }^{2}$ \\ ${ }^{1}$ Department of Civil and Environmental Engineering, The Hong Kong Polytechnic University, Hong Kong \\ ${ }^{2}$ Department of Chemistry, University of California at Irvine, Irvine, CA, USA \\ ${ }^{3}$ Environmental Protection Department, Hong Kong Special Administrative Region, Hong Kong \\ ${ }^{4}$ School of Atmospheric Sciences, Sun Yat-sen University, Guangzhou, China \\ ${ }^{5}$ Guangdong Provincial Key Laboratory of Regional Numerical Weather Prediction, \\ Institute of Tropical and Marine Meteorology, Guangzhou, China \\ Correspondence to: Hai Guo (ceguohai@polyu.edu.hk)
}

Received: 6 October 2015 - Published in Atmos. Chem. Phys. Discuss.: 21 December 2015

Revised: 29 March 2016 - Accepted: 11 May 2016 - Published: 31 May 2016

\begin{abstract}
Many taxis and public buses are powered by liquefied petroleum gas (LPG) in Hong Kong. With more vehicles using LPG, they have become the major contributor to ambient volatile organic compounds (VOCs) in Hong Kong. An intervention program which aimed to reduce the emissions of VOCs and nitrogen oxides $\left(\mathrm{NO}_{x}\right)$ from LPGfueled vehicles was implemented by the Hong Kong government in September 2013. Long-term real-time measurements indicated that the program was remarkably effective in reducing LPG-related VOCs, $\mathrm{NO}_{x}$ and nitric oxide (NO) in the atmosphere. Receptor modeling results further revealed that propane, propene, $i$-butane, $n$-butane and NO in LPGfueled vehicle exhaust emissions decreased by $40.8 \pm 0.1$, $45.7 \pm 0.2,35.7 \pm 0.1,47.8 \pm 0.1$ and $88.6 \pm 0.7 \%$, respectively, during the implementation of the program. In contrast, despite the reduction of VOCs and $\mathrm{NO}_{x}, \mathrm{O}_{3}$ following the program increased by $0.40 \pm 0.03 \mathrm{ppbv}(\sim 5.6 \%)$. The LPGfueled vehicle exhaust was generally destructive to $\mathrm{OH}$ and $\mathrm{HO}_{2}$. However, the destruction effect weakened for $\mathrm{OH}$ and it even turned to positive contribution to $\mathrm{HO}_{2}$ during the program. These changes led to the increases of $\mathrm{OH}, \mathrm{HO}_{2}$ and $\mathrm{HO}_{2} / \mathrm{OH}$ ratio, which might explain the positive $\mathrm{O}_{3}$ increment. Analysis of $\mathrm{O}_{3}-\mathrm{VOC}-\mathrm{NO}_{x}$ sensitivity in ambient air indicated VOC-limited regimes in the $\mathrm{O}_{3}$ formation before and during the program. Moreover, a maximum reduction percentage of $\mathrm{NO}_{x}$ (i.e., 69\%) and the lowest reduction ratio of VOCs $/ \mathrm{NO}_{x}$ (i.e., 1.1) in LPG-fueled vehicle exhaust
\end{abstract}

were determined to give a zero $\mathrm{O}_{3}$ increment. The findings are of great help to future formulation and implementation of control strategies on vehicle emissions in Hong Kong, and could be extended to other regions in China and around the world.

\section{Introduction}

Vehicular exhaust is a major source of air pollutants such as particulate matter (PM), volatile organic compounds (VOCs) and trace gases including carbon monoxide $(\mathrm{CO})$, carbon dioxide $\left(\mathrm{CO}_{2}\right)$, sulfur dioxide $\left(\mathrm{SO}_{2}\right)$ and nitrogen oxides $\left(\mathrm{NO}_{x}\right)$ (Xie et al., 2003; Barletta et al., 2002; Ruellan and Cachier, 2001). Apart from primary pollutants, secondary pollutants formed from vehicular exhausts, i.e., ozone $\left(\mathrm{O}_{3}\right)$ and secondary organic aerosols (SOAs), are of high concern due to their detrimental effects on atmospheric environment and human health (Ciccone et al., 1998).

Fuel substitution is a universal and effective method to constrain vehicular emissions. As relatively clean energy, liquefied petroleum gas (LPG), has been widely used either alone or combined with petrol and diesel (Lau et al., 2011; Lai et al., 2009; Gamas et al., 1999), for the benefit of emission reduction of $\mathrm{CO}_{2}$, fine PM and VOCs (Chikhi et al., 2014; Myung et al., 2012). However, one must bear in mind that maintenance status, conversion method, composi- 
tion and driving speed all influence the emissions of air pollutants (Schifter et al., 2000; Gamas et al., 1999). Therefore, regular on-site measurements are necessary to monitor traffic emission profiles and rates. Although LPG is a relatively clean fuel, the emission of LPG-related VOCs (i.e., propane, propene and $n$ - and $i$-butanes) from evaporation and incomplete combustion cannot be neglected. For example, source apportionment analysis indicated that LPG accounted for a considerable percentage of ambient VOCs in Guangzhou (8-16\%) (Liu et al., 2008) and Hong Kong (32.6 $\pm 5.8 \%)$ (Ou et al., 2015). Furthermore, the LPG-related VOCs can contribute to $\mathrm{O}_{3}$ formation and cause photochemical smog. Blake and Rowland (1995) emphasized the importance of LPG leakage in $\mathrm{OH}$ reactivity and $\mathrm{O}_{3}$ formation in urban Mexico. Farmer et al. (2011) reported that the increase of LPG-related VOCs led to $\mathrm{O}_{3}$ increments even though the total VOCs (TVOCs) were reduced, as the peroxyl radicals $\left(\mathrm{RO}_{2}\right)$ generated from VOCs with low vapor pressure had a higher branching ratio leading to $\mathrm{NO}_{2}$ formation from $\mathrm{NO}$, rather than reserving nitrogen in the form of organic nitrates. On the other hand, NO emitted from LPG combustion may titrate $\mathrm{O}_{3}$. Therefore, it still remains undecided as to whether the LPG usage is contributive or destructive to $\mathrm{O}_{3}$ formation, especially in Hong Kong.

Hong Kong has experienced rapid development during the past decades, and increasingly suffers from crowded traffic and population, with nearly 0.7 million vehicles traveling on the total road length of $2.1 \times 10^{3} \mathrm{~km}$ and 7.2 million people living in a territory $1.1 \times 10^{3} \mathrm{~km}^{2}$ in size. The road usage rate in Hong Kong is among the highest in the world, transporting approximately 1.2 million passengers per day. As such, traffic emissions significantly influence the air quality in Hong Kong. Apart from local emissions, air quality in Hong Kong is also affected by regional transport. In autumn and winter, prevailing northerly and northeasterly winds bring anthropogenic emissions from mainland China to Hong Kong, enhancing local pollution burden. In summer, clean oceanic air masses dilute the levels of air pollutants under the influence of southerly winds (Ling et al., 2013; Guo et al., 2009; Wang et al., 2005; So and Wang, 2003; Chan and Chan, 2000). Ling et al. (2013) quantified the contribution of regional transport as $0-61 \%$ for summer $\mathrm{O}_{3}$ and $0-56 \%$ for autumn $\mathrm{O}_{3}$ on high $\mathrm{O}_{3}$ days in Hong Kong. Guo et al. (2006) found that over $45 \%$ of VOC samples collected from August 2001 to December 2002 at Tai O, Hong Kong, were influenced by regional transport from inland China. Based on numerical simulations, Wang et al. (2006) quantified regional contributions of $40-90 \%$ to $\mathrm{O}_{3}$ formation in Hong Kong, and Huang et al. (2006) indicated that the regional contribution was $<50 \%$ when a trough was over the South China Sea (SCS), and it increased to $>50 \%$ in the presence of an anticyclone over mainland China and/or a tropical cyclone over SCS. Furthermore, Wang et al. (2006) revealed that the regional contribution was lower during daytime than that at night, while Lam et al. (2005) found that the contribution decreased from
$>50 \%$ during an $\mathrm{O}_{3}$ episode to $30-50 \%$ after the episode. In addition, Jiang et al. (2008) reported that the contribution of horizontal transport to surface $\mathrm{O}_{3}$ in Hong Kong was negligible during a typhoon-induced $\mathrm{O}_{3}$ episode. However, all the studies focused on the regional contribution at non-roadside sites, and the $\mathrm{O}_{3}$ chemistry at roadside sites in Hong Kong was seldom reported. Given high $\mathrm{NO}_{x}$ levels, tall buildings and low wind speeds along the main roads in Hong Kong, it is expected that the regional impact on air pollutants in a roadside environment is relatively minor, especially during daytime hours on non- $\mathrm{O}_{3}$ episode days.

To improve the air quality, the Hong Kong Environmental Protection Department (HKEPD) launched a series of programs including a stepwise LPG replacement program for taxis and light buses from 1997. By the end of 2010, > $99 \%$ of the registered taxis (i.e., 17950 vehicles) and $51 \%$ of the registered public and private light buses (i.e., 3280 vehicles) were powered by LPG (HKCSD, 2010). Due to the usage of LPG as vehicle fuel, the ambient VOC profile in Hong Kong changed substantially, with the most abundant species switching from toluene to propane and $n / i$-butanes (Ou et al., 2015; Guo et al., 2007; Ho et al., 2004). In addition, studies consistently confirmed an increased contribution of LPG-fueled vehicle emissions to ambient VOC levels, which was $11 \%$ at an urban site in 2001 (Guo et al., 2004), $15 \%$ at a suburban site during 2002-2003 (Guo et al., 2007) and $26.9 \pm 0.6 \%$ and $40.8 \pm 0.8 \%$ at an urban site during 20022003 and 2006-2007, respectively (Lau et al., 2010). Moreover, $\mathrm{O}_{3}$ has been experiencing an increasing trend in Hong Kong over the last 2 decades (Wang et al., 2009; Guo et al., 2009). As $\mathrm{O}_{3}$ formation was generally VOC-limited in Hong Kong (Cheng et al., 2010; Zhang et al., 2007), the contribution of LPG-fueled vehicle emissions to $\mathrm{O}_{3}$ was not negligible, in view of the dominance of propane and $n / i$-butanes in ambient air and the high contribution of LPG-fueled vehicle emissions to ambient VOC levels. As such, an intervention program which aimed to reduce VOCs and $\mathrm{NO}_{x}$ emitted by LPG-fueled vehicles was initiated in September 2013. This subsidy program promoted the replacement of aging catalytic converters in LPG-fueled vehicles, and the catalytic converters in $\sim 75 \%$ of LPG-fueled vehicles were replaced by the end of May 2014. Although laboratory studies identified a high removal efficiency of the new catalytic converter on VOCs and $\mathrm{NO}_{x}$ emissions (Table $\mathrm{S} 1$ in the Supplement), the impact of the program on roadside air quality, which is more complex, required investigation.

In this study, the effectiveness of the intervention program on the reduction of LPG-related VOCs and $\mathrm{NO}_{x}$, on $\mathrm{O}_{3}$ production and on the photochemical reactivity driving the $\mathrm{O}_{3}$ formation was evaluated. Furthermore, the sensitivity of $\mathrm{O}_{3}$ variation (i.e., the difference of net $\mathrm{O}_{3}$ production by LPG before and during the program) relative to the reduction percentage of LPG-related VOCs and $\mathrm{NO}_{x}$ was studied, and subsequently a maximum $\mathrm{NO}_{x}$ reduction percentage and a 
reasonable reduction ratio of VOCs / $\mathrm{NO}_{x}$ were proposed for achieving the best $\mathrm{O}_{3}$ reduction.

\section{Methodology}

\subsection{Site description}

Hong Kong, located on the coast of the South China Sea (SCS), constitutes the greater Pearl River Delta (PRD) together with Macao and nine mainland cities in Guangdong province (i.e., Guangzhou, Shenzhen, Zhuhai, Foshan, Dongguan, Zhongshan, Huizhou, Jiangmen and Zhaoqing). Hong Kong has a typical coastal hilly terrain, with a large area of water $(\sim 60 \%)$ and large vegetation coverage ( $\sim 70 \%$ of land area). A marine subtropical monsoon climate dominates, and the prevailing winds are north and northeast in winter, east in spring and autumn and south and southwest in summer.

This study involves three roadside sites (Mong Kok (MK, $22.32^{\circ} \mathrm{N}, 114.17^{\circ} \mathrm{E}$ ), Causeway Bay (CWB, $22.28^{\circ} \mathrm{N}$, $\left.114.19^{\circ} \mathrm{E}\right)$ and Central $\left.\left(22.28^{\circ} \mathrm{N}, 114.16^{\circ} \mathrm{E}\right)\right)$, a general site (Tap Mun (TM, 22.47 $\left.\mathrm{N}, 114.36^{\circ} \mathrm{E}\right)$ ) and a background site (Hok Tsui (HT, 22.22 $\mathrm{N}, 114.25^{\circ} \mathrm{E}$ )). MK, CWB and Central are in mixed residential/commercial areas with heavy traffic and are surrounded by dense tall buildings. TM is a rural site surrounded by country parks, and is upwind of Hong Kong in autumn/winter seasons. These four sites have air quality monitoring stations deployed by Hong Kong Environmental Protection Department (HKEPD) (more details are provided at http://www.aqhi.gov.hk/en/monitoring-network/ air-quality-monitoring-stations9c57.html?stationid=81).

HT is a remote site at the tip of southeastern Hong Kong, $\sim 25 \mathrm{~km}$ from the urban core. It receives air masses from SCS in summer and from continental areas including Hong Kong and PRD in autumn/winter. Therefore, air masses at HT are a mix of marine and continental background air. Indeed, HT has been serving as a background site and is extensively used for air quality studies in Hong Kong (Wang et al., 2009; Ho et al., 2006; Lee et al., 2002). Figure 1 shows the geographical location of the sampling sites.

\subsection{Continuous measurements}

\subsubsection{Trace gases}

Five trace gases (i.e., $\mathrm{CO}, \mathrm{SO}_{2}, \mathrm{NO}, \mathrm{NO}_{2}$ and $\mathrm{O}_{3}$ ) were continuously measured at all the sites from 2011 to 2014. The analyzers were deployed in the air quality monitoring stations, with a height of $3.0 \mathrm{~m}$ (MK and CWB), $4.5 \mathrm{~m}$ (Central), $11.0 \mathrm{~m}(\mathrm{TM})$ and $20.0 \mathrm{~m}$ (HT) above ground level. Air samples were drawn through a perfluoroalkoxy (PFA) Teflon tube with an outside diameter (OD) of $12.7 \mathrm{~mm}$ and an inside diameter (ID) of $9.6 \mathrm{~mm}$. The inlet of the tube was approximately $0.5 \mathrm{~m}$ above the rooftop of the monitoring station, and

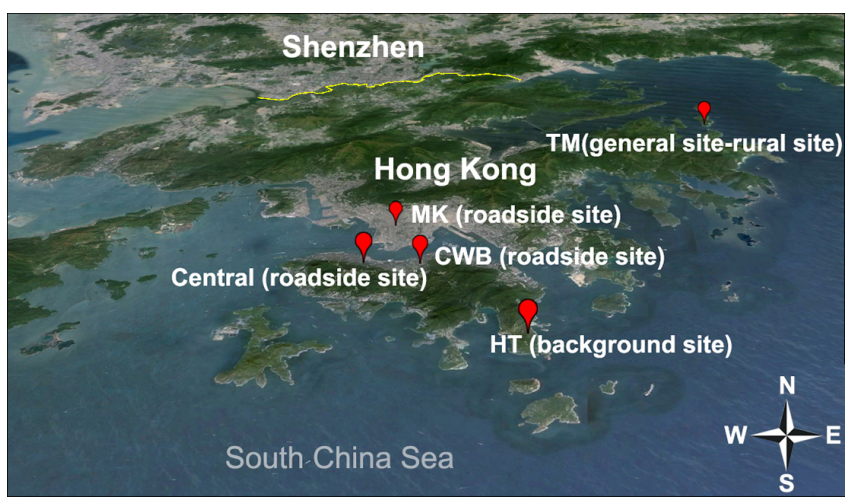

Figure 1. Geographical location of the sampling sites. The yellow line represents the border between Hong Kong and mainland China.

the outlet was connected to a PFA manifold with a bypass pump, drawing air into the analyzers at a rate of $5 \mathrm{~L} \mathrm{~min}^{-1}$. Details about the analyzers are provided elsewhere (HKEPD, 2014; So and Wang, 2003).

Briefly, CO was analyzed using the method of nondispersive infrared absorption with gas filter correlation (TECO 48C/API 300); $\mathrm{SO}_{2}$ was detected with UV fluorescence analyzers (TECO 43A/API 100E/TECO 43I); NO$\mathrm{NO}_{2}-\mathrm{NO}_{x}$ were measured by chemiluminescence technique (API 200A); and $\mathrm{O}_{3}$ was monitored with the UV absorption method (API 400/API 400A). The detection limits for CO, $\mathrm{SO}_{2}, \mathrm{NO}, \mathrm{NO}_{2}$ and $\mathrm{O}_{3}$ were 50.0, 1.0, 0.5, 0.5 and $2.0 \mathrm{ppbv}$, respectively.

\subsubsection{VOCs}

Thirty $\mathrm{C}_{2}-\mathrm{C}_{10}$ non-methane hydrocarbons (NMHCs), including 11 alkanes, 10 alkenes and 9 aromatics, were continuously measured at MK and HT from 2011 to 2014. The VOC samples were collected and analyzed every $30 \mathrm{~min}$ with an online analytical system (Syntech Spectra GC 955, Series $600 / 800$, the Netherlands). The data were averaged into hourly values. The detection limits varied by VOC species and were in the range of $0.002-0.787 \mathrm{ppbv}$.

Table S2 summarizes average mixing ratios of the main VOCs and trace gases, and their $\mathrm{OH}$ reactivity at the roadside (MK) and background site (HT) before (October 2012September 2013) and during the program (October 2013May 2014) in Hong Kong. The much higher $\mathrm{OH}$ reactivity at MK (before: $86.6 \pm 6.0 \mathrm{~s}^{-1}$; during: $77.9 \pm 6.1 \mathrm{~s}^{-1}$ ) than at HT (before: $5.0 \pm 0.3 \mathrm{~s}^{-1}$; during: $\left.4.9 \pm 0.1 \mathrm{~s}^{-1}\right)$ meant that the $\mathrm{OH}$ lifetime was much shorter at $\mathrm{MK}(\sim 0.01 \mathrm{~s})$ than at HT $(0.2 \mathrm{~s})$, and even shorter than that at an urban site in New York (0.05 s) (Ren et al., 2003), indicating that reactive species were extremely abundant in the roadside environment of Hong Kong. The LPG-related VOCs (i.e., propane and $n / i$-butanes) contributed $56.5 \pm 2.7$ and $46.0 \pm 3.1 \%$ to total VOCs, and $18.7 \pm 1.2$ and $15.1 \pm 1.1 \%$ to the total $\mathrm{OH}$ reactivity of VOCs at MK, before and during the program, 
respectively. These fractional contributions suggest the importance of LPG-related VOCs in the budgets of VOCs and $\mathrm{O}_{3}$ in Hong Kong. Consistent with the decreases of fractional contributions once the program started, the mixing ratios $(29.4 \pm 3.3$ and $21.0 \pm 2.2 \mathrm{ppbv}$ for before and during the program, respectively) and $\mathrm{OH}$ reactivity $(1.12 \pm 0.04$ and $0.79 \pm 0.02 \mathrm{~s}^{-1}$ before and during the program, respectively) of LPG-related VOCs significantly declined at MK $(p<0.05)$, while at HT, their mixing ratios increased from $1.5 \pm 0.1$ to $1.9 \pm 0.04 \mathrm{ppbv}$, and the $\mathrm{OH}$ reactivity increased from $0.06 \pm 0.004$ to $0.07 \pm 0.003 \mathrm{~s}^{-1}$. The minor variation of background LPG-related VOCs relative to the decreases at $\mathrm{MK}(4.8 \%$ in mixing ratios and $3.0 \%$ in $\mathrm{OH}$ reactivity of VOCs) indicated that the influences of the background concentrations on the variations of LPG-related VOCs and $\mathrm{O}_{3}$ at MK were minimal and can be neglected.

\subsubsection{Quality assurance and control (QA/QC)}

To guarantee the quality of the data acquired from the online monitoring systems, the instruments and QA/QC procedures for trace gases measurements were identical to those in the US air quality monitoring program (http://epic.epd.gov. $\mathrm{hk} / \mathrm{ca} / \mathrm{uid} / \mathrm{airdata}$ ). The measurements have been accredited by the Hong Kong Laboratory Accreditation Scheme (HOKLAS). All the instruments were regularly calibrated, tested and audited by standards with known traceability for measurements of trace gases. According to HOKLAS criteria, a quality system was established to control the accuracy and precision within the limits of \pm 15 and $\pm 20 \%$, respectively (HKEPD, 2014). For VOC analysis, a built-in computerized program, including auto-linearization, auto-calibration and calibration with span gas, was adopted to control the quality. The accuracy and precision of VOC measurements were $1.0-10 \%$ and $2.5-20 \%$, respectively. The accuracy was based on weekly span checks, monthly calibration and annual auto-linearization using the National Physical Laboratory (NPL) span gas. The precision was based on quarterly precision check results (the $95 \%$ probability limits for the integrated precision based on weekly precision check results of the latest 3 months). Moreover, the online measurements of VOCs were regularly compared with whole-air canister samples collected and analyzed by University of California at Irvine (UCI). Good agreements were identified for the alkanes (e.g., $R^{2}=0.95$ and 0.85 , slope $=1.14$ and 0.97 for propane and butanes, respectively), while the agreements for the more reactive alkenes and aromatics were also reasonable (e.g., $R^{2}=0.64$ and 0.94 , slope $=1.34$ and 0.86 for propene and toluene, respectively).

\subsection{Theoretical calculation and model description}

\subsubsection{Primary emissions of VOCs and $\mathrm{NO}_{x}$}

The measured concentrations of VOCs and trace gases were composed of the backgrounds, primary emissions and secondary formation (applicable to $\mathrm{O}_{3}$ and $\mathrm{NO}_{2}$ ). To obtain the concentrations of LPG-related VOCs and $\mathrm{NO}_{x}$ emitted from primary sources at the roadside sites, the background concentrations and the concentrations elevated by the secondary formation (if applicable) in this study were excluded using Eqs. (1)-(5) (Takekawa et al., 2013):

$$
\begin{aligned}
& {[\mathrm{VOC}]_{\text {prim. }}=[\mathrm{VOC}]_{\text {obs. }}-[\mathrm{VOC}]_{\text {bg. }}} \\
& {\left[\mathrm{NO}_{2}\right]_{\text {sec. }}=\left[\mathrm{O}_{3}\right]_{\text {bg. }}-\left[\mathrm{O}_{3}\right]_{\text {obs. }}} \\
& {\left[\mathrm{NO}_{2}\right]_{\text {prim. }}=\left[\mathrm{NO}_{2}\right]_{\text {obs. }}-\left[\mathrm{NO}_{2}\right]_{\text {sec. }}-\left[\mathrm{NO}_{2}\right]_{\text {bg. }}} \\
& {\left[\mathrm{NO}_{x}\right]_{\text {prim. }}=\left[\mathrm{NO}_{x}\right]_{\text {obs. }}-\left[\mathrm{NO}_{x}\right]_{\text {bg. }}} \\
& {[\mathrm{NO}]_{\text {prim. }}=\left[\mathrm{NO}_{x}\right]_{\text {prim. }}-\left[\mathrm{NO}_{2}\right]_{\text {prim. }}}
\end{aligned}
$$

where $[x x]_{\text {obs. }},[x x]_{\text {prim. }},[x x]_{\text {sec. }}$ and $[x x]_{\text {bg. }}$. represent the observed concentrations, the concentrations emitted from primary sources, secondary formation and the backgrounds, respectively. In this study, the hourly measured VOCs at HT were considered as the background levels for VOCs. For $\mathrm{O}_{3}$ and $\mathrm{NO}_{x}$, the $8 \mathrm{~h}$ averages at TM were treated as background values because (1) $\mathrm{O}_{3}$ and $\mathrm{NO}_{x}$ are highly reactive, and the use of $8 \mathrm{~h}$ averages would minimize the impact of abrupt changes; (2) TM is located at the upwind location of Hong Kong, and is a rural coastal site; (3) $8 \mathrm{~h}$ averages of $\mathrm{O}_{3}$ and $\mathrm{NO}_{x}$ showed good correlations $\left(R^{2}=0.75\right.$ and 0.57 for $\mathrm{O}_{3}$ and $\mathrm{NO}_{x}$, respectively) between TM and HT, and not all the data were available at HT during the entire study period.

\subsubsection{Impact of regional and super-regional air masses}

Since MK was the only roadside site with VOC and trace gas data, this study mainly focused on the data analysis of this site. As a roadside site, MK was expected to be strongly influenced by fresh vehicular emissions. VOC ratios can indicate the relative ages of air masses and regional transport of air pollutants. For example, the ratios of VOCs with higher reactivity to those with lower reactivity (e.g., toluene / benzene and xylenes / ethylbenzene) imply more fresh air when values are higher, which has been extensively used in previous studies (Guo et al., 2007; Ho et al., 2004). Therefore, ratios of toluene / benzene and xylenes / ethylbenzene were calculated here to roughly estimate the age of air masses at MK. Table 1 summarizes the ratios at MK (roadside site), Tung Chung (TC) and Yuen Long (YL) (both general ambient sites) and HT (background site) in Hong Kong from October 2012 to May 2014. It is noteworthy that ambient VOCs at all the four sites were simultaneously measured. The ratios of toluene / benzene and xylenes / ethylbenzene at MK were significantly higher than those at the other three sites $(p<0.05)$. Furthermore, these ratios at MK were even 


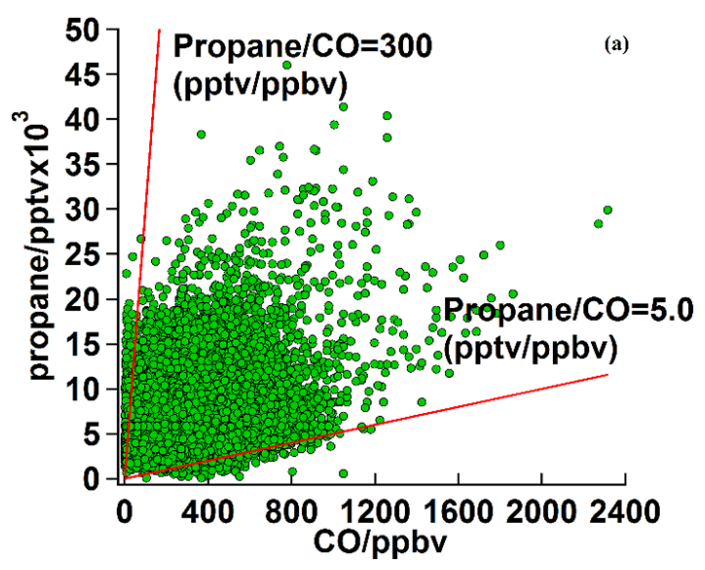

Figure 2. Hourly ratio of propane / CO at MK during 2011-2014.

higher after the background values were deducted. The results suggested that air masses at MK were dominated by fresh emissions.

However, regional and super-regional transport cannot be completely eliminated only with the VOC ratios, and the influence of regional/super-regional air should be further examined when studying the emissions of local LPG-fueled vehicles. Using the propane / CO ratio method proposed by Guo et al. (2006), i.e., the ratio range of 5.0-300 pptv ppbv ${ }^{-1}$ for air masses in Hong Kong, the influence of regional/superregional air masses on local air was evaluated. Figure 2 shows the ratios of propane / CO at MK from 2011 to 2014. The propane / CO ratios of $\sim 96 \%$ air masses were between 5.0 and $300 \mathrm{pptv} \mathrm{ppbv}^{-1}$. Further inspection of the values of LPG-related VOCs and $\mathrm{NO}_{x}$ with ratios of 5.0-300 showed insignificant differences $(p>0.1)$ to those with ratios beyond 5-300, suggesting that the air masses at MK were seldom influenced by regional/super-regional air. Moreover, wind speeds were lower than $2.0 \mathrm{~m} \mathrm{~s}^{-1}$ for more than $95 \%$ of the time (i.e., calm or light air according to the Beaufort Wind Scale) (http://www.spc.noaa.gov/faq/tornado/beaufort.html), and the values of LPG-related VOCs and $\mathrm{NO}_{x}$ in all air masses were not different to those in the air masses with wind speeds lower than $2.0 \mathrm{~m} \mathrm{~s}^{-1}(p>0.1)$, confirming a minor impact of regional/super-regional pollution on air at MK. Indeed, the prevailing wind direction was from the east, where local urban areas are located.

\subsubsection{PMF model}

Positive matrix factorization (PMF) is a receptor model for source apportionment and has been extensively used in many fields (i.e., PM, VOCs and sediment) (Brown et al., 2007; Lee et al., 1999). Based on the principle of mass balance, it decomposes the matrix of measurement $(\mathbf{X})$ into the matrices of factor contributions $(\mathbf{G})$ and factor profiles $(\mathbf{F})$ in $p$ sources, as shown in Eq. (6) (Paatero, 1997; Paatero and
Tapper, 1994):

$x_{i j}=\sum_{k=1}^{p} g_{i k} f_{k j}+e_{i j}$,

where $x_{i j}$ is the measured concentration of $j$ species in $i$ sample, $g_{i k}$ represents the contribution of $k$ th source to $i$ sample, $f_{k j}$ indicates the fraction of $j$ species in $k$ th source and $e_{i j}$ is the residual for $j$ species in $i$ sample.

The matrices of $G$ and $F$ are obtained in the case of the minimum of objective function $\mathbf{Q}$, as shown in Eq. (7):

$\mathbf{Q}=\sum_{i=1}^{n} \sum_{j=1}^{m}\left[\frac{x_{i j}-\sum_{k=1}^{p} g_{i k} f_{k j}}{u_{i j}}\right]^{2}$

where $m$ and $n$ represent the number of species and samples, respectively, and $u_{i j}$ is the uncertainty of $j$ species in $i$ sample. $Q$ (robust) is automatically calculated by excluding the points not fit by the model, and the run with lowest $Q$ (robust) value is selected as the optimum solution by the model.

\subsubsection{PBM-MCM model}

The photochemical box model incorporating the master chemical mechanism (PBM-MCM) is a computing model based on the chemical reactions of observed species. It has been introduced and successfully applied in many previous studies in reproducing the observed values, describing the production and destruction mechanisms and simulating the photochemical reactivity (Ling et al., 2014; Lam et al., 2013; Cheng et al., 2010). Briefly, the observations of VOCs, trace gases and meteorological parameters are input to construct and constrain the model, which consists of 5900 reactions and 16500 species in the latest version (MCM 3.2). However, it is noteworthy that the heterogeneous reactions are not included, and the model does not consider the transport processes (i.e., horizontal and vertical transport).

In this study, $\mathrm{CO}, \mathrm{SO}_{2}, \mathrm{NO}, \mathrm{NO}_{2}, \mathrm{O}_{3}, 27 \mathrm{VOCs}$ and two meteorological parameters (i.e., temperature and relative humidity) were used to construct and constrain the model. Hourly data were used as input (i.e. $24 \mathrm{~h}$ per day) and the outputs were from 07:00 to 19:00 by each hour. To better describe the photochemical reactions in Hong Kong, the model was modified; i.e., the photolysis rates were calibrated using the photon fluxes from the Tropospheric Ultraviolet and Visible Radiation (TUV-v5) model (Madronich and Flocke, 1997), according to the location of Hong Kong and the modeling period, and the height of the mixing layer was set as $300-1400 \mathrm{~m}$. The concentrations of some species in the free troposphere, which may influence the mixing ratios of air pollutants in the lower troposphere with the development of boundary layer, were set according to the real conditions in Hong Kong (Lam et al., 2013). 
Table 1. Ratios of toluene / benzene and xylenes / ethylbenzene at MK and other sites in Hong Kong from October 2012 to May 2014 (unit: ppbv ppbv $\left.{ }^{-1}\right)$.

\begin{tabular}{lll}
\hline & Toluene / benzene & Xylenes / ethylbenzene \\
\hline MK (roadside site) & $4.1 \pm 0.04$ & $3.0 \pm 0.02$ \\
MK (roadside site) & $11.3 \pm 0.9$ & $5.7 \pm 0.2$ \\
TC (general site) & $0.7 \pm 0.1$ & - \\
YL (general site) & $3.7 \pm 0.04$ & $2.4 \pm 0.02$ \\
HT (background site) & $2.5 \pm 0.1$ & $1.8 \pm 0.03$ \\
\hline
\end{tabular}

MK* refers to VOCs at MK with the background values removed.

Table 2. Formation and loss pathways of $\mathrm{OH}$ and $\mathrm{HO}_{2}$ considered in this study.

\begin{tabular}{lll}
\hline & $\mathrm{OH}$ & $\mathrm{HO}_{2}$ \\
\hline Formation pathways & $\mathrm{HO}_{2}+\mathrm{NO}$ & $\mathrm{RO}_{2}+\mathrm{NO}$ \\
& $\mathrm{HONO}+h v$ & $\mathrm{OH}+\mathrm{CO}$ \\
& $\mathrm{O}\left({ }^{1} \mathrm{D}\right)+\mathrm{H}_{2} \mathrm{O}$ & $\mathrm{OH}+\mathrm{HCHO}$ \\
& $\mathrm{O}_{3}+$ alkenes & $\mathrm{HCHO}+h v$ \\
& & $\mathrm{O}_{3}+$ alkenes \\
\hline Loss pathways & $\mathrm{OH}+\mathrm{VOCs}$ & $\mathrm{HO}_{2}+\mathrm{NO}$ \\
& $\mathrm{OH}+\mathrm{NO}_{2}$ & \\
& $\mathrm{OH}+\mathrm{CO}$ & \\
& $\mathrm{OH}+\mathrm{NO}$ & \\
\hline
\end{tabular}

A base case was established to simulate $\mathrm{O}_{3}$ and the photochemical reactivity (i.e., the formation and loss pathways of $\mathrm{OH}$ and $\mathrm{HO}_{2}$ listed in Table 2). The observed VOCs and trace gases were input to construct the base case, and the simulated $\mathrm{O}_{3}$ was compared with the observed levels to validate the model and check the influence of regional transport during daytime hours. At low wind speed $\left(1.3 \pm 0.01 \mathrm{~m} \mathrm{~s}^{-1}\right)$ and high $\mathrm{NO}_{x}(223.2 \pm 1.8 \mathrm{ppbv})$ at $\mathrm{MK}$, the majority of regional $\mathrm{O}_{3}$ would be completely consumed before being detected by measurement instruments. In fact, the PBM-MCM model considered the regionally transported concentrations of $\mathrm{O}_{3}$ precursors, as the observed concentrations input into the model included the regional fractions. Moreover, since $\mathrm{O}_{3}$ levels were higher at night $(8.1 \pm 0.2 \mathrm{ppbv})$ than those during daytime $(5.9 \pm 0.1 \mathrm{ppbv})$ at $\mathrm{MK}$, it suggests the existence of nocturnal regional transport. Hence, the observed $\mathrm{O}_{3}$ at 07:00 was input into the model to initiate the simulation for daytime hours; i.e., the nocturnal regional transport of $\mathrm{O}_{3}$ was also considered.

To simulate the contribution of LPG source to $\mathrm{O}_{3}$ formation, the following approach was adopted to avoid altering the real ambient environment for atmospheric chemistry. Briefly, the concentration of species $X$ in the whole air and in the assigned LPG source was defined as $X_{\text {whole air }}$ and $X_{\mathrm{LPG}}$, respectively. Hence, the concentration of $X_{\text {whole air }}-X_{\mathrm{LPG}}$ was the input for the constrained cases, while $X_{\text {whole air }}$ was the input for the base case. The three constrained cases were as follows: (i) only VOCs in the LPG source were excluded from the whole air; (ii) only $\mathrm{NO}_{x}$ in the LPG source was excluded; and (iii) both VOCs and $\mathrm{NO}_{x}$ were removed simultaneously. As such, the differences of the outputs between the base case and the three constrained cases were the contributions of (i) VOCs, (ii) $\mathrm{NO}_{x}$ and (iii) VOCs $+\mathrm{NO}_{x}$ in the LPG source to the $\mathrm{O}_{3}$ formation, respectively. The changes of these contributions from the period before the program to during the program represented the impact of the intervention program on $\mathrm{O}_{3}$ formation. Table $\mathrm{S} 3$ in the Supplement lists the configurations of the model input for the base case and the three constrained cases.

\subsubsection{Relative incremental reactivity (RIR)}

RIR, initially proposed by Carter and Atkinson (1989), has been extensively used to describe the relationship between $\mathrm{O}_{3}$ and its precursors, i.e., VOCs, $\mathrm{NO}_{x}$ and $\mathrm{CO}$. Although the observation-based models incorporating carbon bond mechanisms were often utilized to simulate the $\mathrm{O}_{3}$ production rate (Ling et al., 2011; Zhang et al., 2007; Martien et al., 2003), a more explicit PBM-MCM model was applied in this study. The RIR and RIR (weighted concentration) were calculated using Eqs. (8) and (9) (Ling et al., 2011):

$$
\begin{aligned}
& \operatorname{RIR}^{\mathrm{S}}(X)= \\
& \frac{\left[P_{\mathrm{O}_{3}-\mathrm{NO}}^{\mathrm{S}}(X)-P_{\mathrm{O}_{3}-\mathrm{NO}}^{\mathrm{S}}(X-\Delta X)\right] / P_{\mathrm{O}_{3}-\mathrm{NO}}^{\mathrm{S}}(X)}{\Delta S(X) / S(X)} \\
& \mathrm{RIR}(\text { weighted concentration) }=\mathrm{RIR}(X) \\
& \times \text { concentration RIR (weighted concentration) } \\
& =\mathrm{RIR}(X) \times \text { concentration, }
\end{aligned}
$$

where $\mathrm{P}_{\mathrm{O}_{3}-\mathrm{NO}}^{\mathrm{S}}(X)$ and $\mathrm{P}_{\mathrm{O}_{3}-\mathrm{NO}}^{\mathrm{S}}(X-\Delta X)$ represent the original $\mathrm{O}_{3}$ production rate, and that in the scenario, with a hypothetical change $(\Delta X)(10 \%$ in this study) in source/species $X$, respectively, both of which considered $\mathrm{O}_{3}$ titration by NO. $\Delta S(X)$ is the change in the concentration of $X(S(X))$. The concentration refers to the observed or PMFextracted concentration of source/species $X$. 
Table 3. Mixing ratios of LPG-related VOCs and $\mathrm{NO}_{x}$ during the period before the program, the matched period and the period during the program (unit: ppbv).

\begin{tabular}{llll}
\hline Species & Before & During & Matched \\
\hline Propane & $8.5 \pm 0.1$ & $5.8 \pm 0.1$ & $9.1 \pm 0.1$ \\
$i$-butane & $6.6 \pm 0.1$ & $4.7 \pm 0.1$ & $6.9 \pm 0.1$ \\
$n$-butane & $13.2 \pm 0.2$ & $8.4 \pm 0.1$ & $13.7 \pm 0.2$ \\
$\mathrm{NO}$ & $201.7 \pm 2.1$ & $172.0 \pm 2.7$ & $201.9 \pm 2.7$ \\
$\mathrm{NO}_{2}$ & $25.9 \pm 0.3$ & $23.8 \pm 0.4$ & $26.8 \pm 0.4$ \\
$\mathrm{NO}_{x}$ & $229.4 \pm 2.3$ & $197.7 \pm 3.0$ & $231.2 \pm 2.9$ \\
\hline
\end{tabular}

\section{Results and discussion}

\subsection{Variations of LPG-related VOCs and $\mathrm{NO}_{x}$ during the intervention program}

\subsubsection{Concentrations of primary LPG-related VOCs and $\mathrm{NO}_{x}$}

Table 3 shows the mixing ratios of the primarily emitted LPG-related VOCs and $\mathrm{NO}_{x}$ before and during the program. The LPG-related VOCs and $\mathrm{NO}_{x}$ were reduced significantly from the period before the program to during the program $(p<0.05)$. To investigate the meteorological influences on these reductions, we looked into the average geopotential height (HGT) and wind field on $1000 \mathrm{hPa}$ for East Asia for the matched period and the period during the program, as shown in Fig. S1 in the Supplement (the matched period (October 2012-May 2013) was defined as the same time span as that during the program, but in different years.) Noticeably, the meteorological conditions were fairly similar between the two periods; i.e., the pressure decline (indicated by the decrease of HGT) from northern China to SCS led to the prevailing northeasterly winds in Hong Kong, and the differences of HGT and wind speed between the two periods for Hong Kong were only 0-2 gpm and less than $1 \mathrm{~m} \mathrm{~s}^{-1}$, respectively. Ground monitoring data also indicated insignificant differences of temperature (matched: $21.9 \pm 0.5^{\circ} \mathrm{C}$; during: $21.2 \pm 0.7^{\circ} \mathrm{C}$ ) between the two periods $(p>0.05)$. However, the mixing ratios of LPG-related VOCs and $\mathrm{NO}_{x}$ during the matched period were comparable to those before the program, and absolutely higher than those during the program $(p<0.05)$ (see Table 3). Given the similar meteorological conditions between the matched period and during the program, the significant decreases of LPG-related VOCs and $\mathrm{NO}_{x}$ were caused by the interventional program, rather than meteorological variations.

To further understand the effectiveness of the program, the monthly reductions of LPG-related VOCs after the commencement of the converter replacement were calculated and compared with those before the program (Fig. 3). Since the program was initiated in October 2013, the averages of VOC species in September in each year were taken as the base- lines for the calculation of monthly reduction. Briefly, the monthly reductions of LPG-related VOCs were the differences between their averages in September and those in the other months. Hence, positive and negative values indicate reductions and increments of the corresponding species, respectively. It was found that the monthly averages of LPGrelated VOCs consistently decreased from September 2013 to May 2014 except for $n$-butane in October 2013 when the program was just initiated. Compared to those before the program (i.e. September 2013), the mixing ratios of propane, $i$-butane and $n$-butane decreased $3.2 \pm 0.2,2.8 \pm 0.2$ and $4.9 \pm 0.2$ ppbv by May 2014, respectively, when $99.2 \%$ of catalytic converters participating in the program had been exchanged. Furthermore, the monthly reductions correlated well with the cumulative converter replacements $\left(R^{2}=0.92\right.$, 0.93 and 0.89 for propane, $i$-butane and $n$-butane, respectively). In contrast, no consistent reduction was observed from September 2012 to May 2013 for LPG-related VOCs, suggesting the effectiveness of the program on the reduction of LPG-related VOCs. On the other hand, although the average mixing ratios of $\mathrm{NO}_{x}$ decreased significantly during the program as shown in Table 3, no consistent reductions were found for their monthly averages. This might be due to the fact that $\mathrm{NO}_{x}$ emitted from LPG-fueled vehicles was minor compared to gasoline- and diesel-fueled vehicles $(\sim 4.0 \%$ from emission inventory, and 1.1-7.3\% from source apportionment. See Sect. 3.2.2).

\subsubsection{Temporal variations of primary LPG-related VOCs and $\mathrm{NO}_{x}$}

Figure 4 presents the temporal variations of propane and $n / i$ butanes at MK from June 2013 to May 2014 covering the periods of both before (i.e., June-September 2013) and during the intervention program (i.e., October 2013-May 2014). The abnormally low alkane levels in late June 2013 might be caused by the anticyclone over southern China and a tropical storm over the SCS, leading to extremely high temperature on 18-20 June (i.e., favorable for photochemical reactions), and stronger winds (i.e., conducive to atmospheric dispersion) on the following days, respectively. In contrast, Hong Kong was strongly influenced by an active ocean flow and a low pressure trough over the SCS in late July 2013. The consequently heavy rain and low temperature suppressed the photochemical reactions and caused the unusually high levels of VOCs (Fig. S2 in the Supplement illustrates these events). Generally, the LPG-related VOCs experienced a significant $(p<0.05)$ reduction throughout the year. The daily changing rates of LPG-related VOCs in two periods, i.e., SeptemberDecember and January-May, in different years at MK are shown in Table 4. It is noteworthy that the two periods were selected based on data availability each year, and the minimized influence of meteorological parameters in the same month of different years. The LPG-related VOCs decreased from September to December in 2011 and 2013, but there 

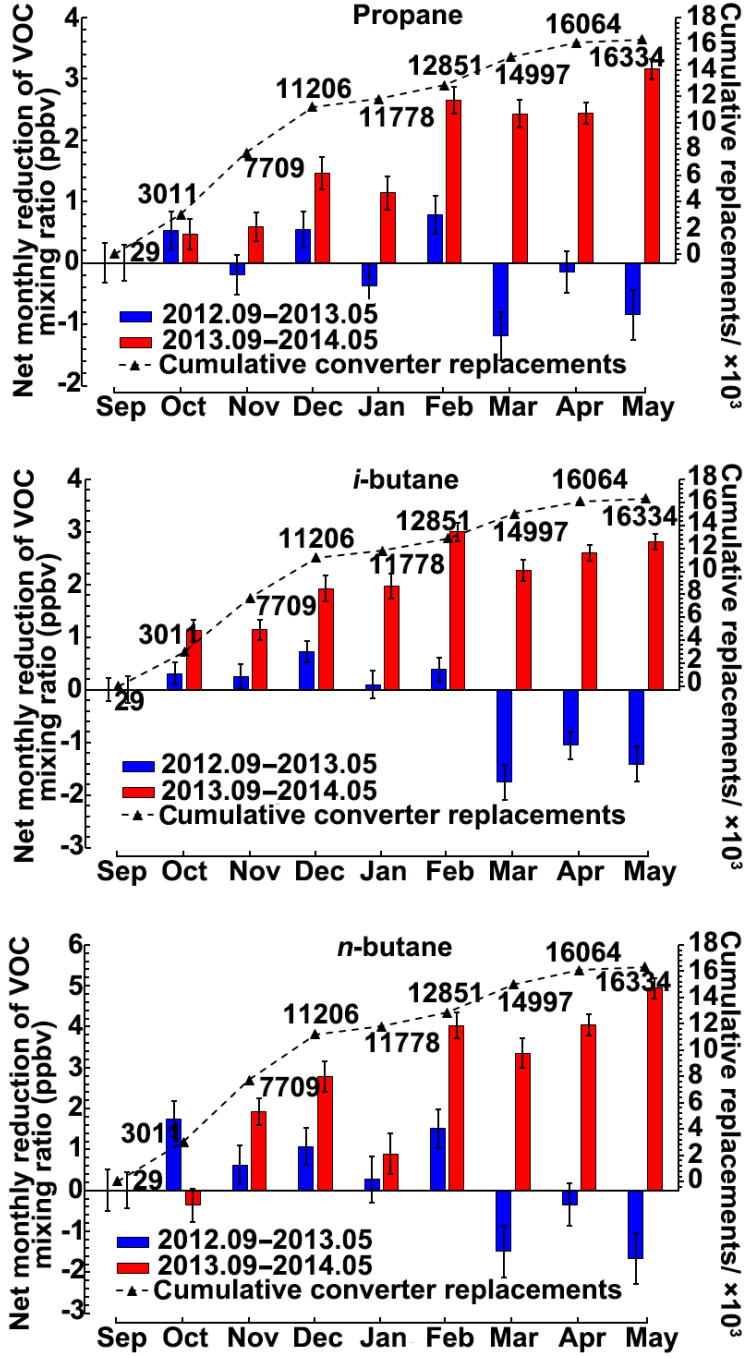

Figure 3. Monthly reductions of LPG-related VOCs at MK before (blue bar) and during (red bar) the program. (The average value of VOC species in September is the baseline. The values along the dot line were the cumulative numbers of converters replaced. The bars above and below the $x$ axis refer to the reduction and increase of VOC mixing ratio, respectively.)

was no significant difference in 2012. In general, the levels of VOCs in the atmosphere are associated with source emissions, photochemical reactions and regional transport. As the regional influence was excluded in this study, source emissions and photochemical reactions became the main factors determining the ambient concentrations of VOCs. The decreasing and unchanged trends in 2011 and 2012 respectively might be related to the integrated influence of reduced photochemical degradation (which increases ambient VOC levels) and temperature decrease (which reduces evaporative emissions of VOCs) from September to December. It is noticeable that the LPG-related VOCs had the highest decreasing rates in September-December 2013, compared to

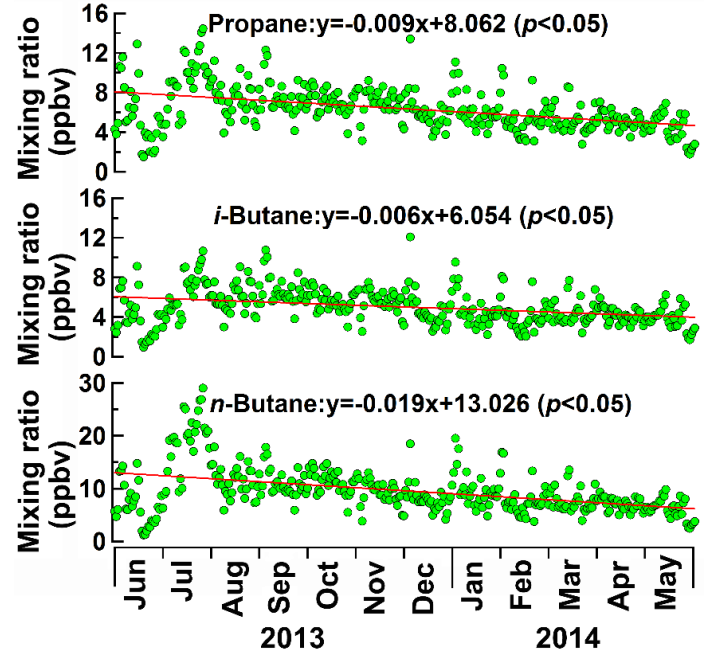

Figure 4. Variation trends of the daily average propane and $n / i$ butanes at MK from June 2013 to May 2014. In the equation, label $x$ has a unit of days.

those in previous years. The higher decreasing rates of LPGrelated VOCs in September-December 2013 implied the possible effectiveness of the interventional program on VOCs reduction. For the period of January-May, the LPG-related VOCs increased in January-May 2013, except for propane which did not show significant change from January to May. However, significant decreasing trends $(p<0.05)$ were observed for propane and $n / i$-butanes during the same period in 2014, which was likely owing to the continuous replacement of catalytic converters on LPG-fueled vehicles. By comparison, the reduction rates of LPG-related VOCs in January-May 2014 were all lower than those in SeptemberDecember 2013. This was mainly attributable to the fact that a large portion (i.e. $\sim 69 \%$ ) of the converter replacements were completed by the end of December 2013, and there were much fewer replaced converters (i.e. $\sim 31 \%$ ) in January-May 2014.

Figure 5 shows the temporal variations of primary $\mathrm{NO}_{x}$, $\mathrm{NO}, \mathrm{NO}_{2}$ and secondary $\mathrm{NO}_{2}$ at MK from June 2013 to May 2014. The primary $\mathrm{NO}_{x}$ and $\mathrm{NO}$ mixing ratios decreased significantly $(p<0.05)$, implying the possible effectiveness of the intervention program on $\mathrm{NO} / \mathrm{NO}_{x}$ reduction. However, the secondary $\mathrm{NO}_{2}$ levels increased, while there was no significant change $(p>0.05)$ for primary $\mathrm{NO}_{2}$. To explore the reasons of $\mathrm{NO}-\mathrm{NO}_{2}-\mathrm{NO}_{x}$ variations, the changing rates of primary $\mathrm{NO}_{x}, \mathrm{NO}, \mathrm{NO}_{2}$ and secondary $\mathrm{NO}_{2}$ during the same period (i.e., June in the previous year to May in the following year) in different years were compared. Table 5 shows the statistics of changing rates of $\mathrm{NO}_{x}-\mathrm{NO}$ $\mathrm{NO}_{2}$ at the roadside sites (i.e., $\mathrm{MK}, \mathrm{CWB}$ and Central) from June 2011 to May 2014. Taking MK as an example, the primary $\mathrm{NO}_{x}$ and $\mathrm{NO}$ decreased much faster (i.e., 91 and 94 pptv day $^{-1}$, respectively) from June 2013 to May 2014 
Table 4. Changing rates of propane and $n / i$-butanes in SeptemberDecember and January-May in different years (ppbv day ${ }^{-1}$ ).

\begin{tabular}{rlrrrrr}
\hline \multicolumn{2}{c}{ Time period } & \multicolumn{3}{c}{ Sep-Dec } & \multicolumn{2}{c}{ Jan-May } \\
Site & Species & 2011 & 2012 & 2013 & 2013 & 2014 \\
\hline \multirow{2}{*}{ MK } & Propane & -0.015 & $-0.004^{*}$ & $\mathbf{- 0 . 0 1 7}$ & $0.004^{*}$ & $\mathbf{- 0 . 0 1 4}$ \\
& $i$-butane & -0.010 & $-0.008^{*}$ & $\mathbf{- 0 . 0 2 1}$ & 0.012 & $\mathbf{- 0 . 0 0 5}$ \\
& $n$-butane & -0.023 & $-0.009^{*}$ & $\mathbf{- 0 . 0 3 9}$ & 0.016 & $\mathbf{- 0 . 0 2 8}$ \\
* The changing rate insignificant $(p>0.05)$; the bold numbers are changing rates during the
\end{tabular}

implementation of the program.

than during the same period in 2011-2012 and 2012-2013, suggesting the effectiveness of the program in reducing $\mathrm{NO}_{x}$ and NO. Compared to the decreasing rate in June 2012May 2013 (i.e., 13 pptv day ${ }^{-1}$ ), no significant change $(p>$ $0.05)$ was observed for primary $\mathrm{NO}_{2}$ from June 2013 to May 2014. However, it cannot be concluded that the program caused the increase of primary $\mathrm{NO}_{2}$, in view of the same insignificant variation in June 2011-May 2012 and the fact that LPG-fueled vehicles emit negligible $\mathrm{NO}_{2}$ (see Sect. 3.2.2). In contrast, secondary $\mathrm{NO}_{2}$ significantly increased (with a rate of 13 pptv day $^{-1}$ ) from June 2013 to May 2014, which was also observed in June 2011-May 2012 (i.e., increasing rate of 20 pptv day ${ }^{-1}$ ). Since secondary $\mathrm{NO}_{2}$ is formed by $\mathrm{NO}$ reacting with $\mathrm{O}_{3}$, inspection of the $\mathrm{O}_{3}$ production would provide more comprehensive interpretation on the secondary $\mathrm{NO}_{2}$ increment during the program. Similar variations were observed at CWB and Central, where primary $\mathrm{NO}_{x}$ and $\mathrm{NO}$ showed significant decreasing trends, whereas the variations of primary and secondary $\mathrm{NO}_{2}$ were insignificant $(p>0.05)$.

In summary, the LPG-related VOCs were significantly lowered during the program with monthly reductions of $3.2 \pm 0.2,2.8 \pm 0.2$ and $4.9 \pm 0.2 \mathrm{ppbv}$ for propane, $i$-butane and $n$-butane by the end of this study, respectively. Continuous decreasing trends were observed for LPG-related VOCs, and the reduction rates were almost unprecedented, e.g., 39 pptv day $^{-1}$ for $n$-butane. Furthermore, the mixing ratios of $\mathrm{NO}$ and $\mathrm{NO}_{x}$ decreased as well during the program. The reduction rates of $\mathrm{NO}$ and $\mathrm{NO}_{x}$ during June 2013-May 2014 at the three roadside sites were much higher than those in previous years. Overall, the field measurement data indicated that the program was effective in reducing emissions of LPGrelated VOCs and $\mathrm{NO}_{x}$.

\subsection{Variations of LPG contributions to VOCs and $\mathrm{NO}_{x}$}

\subsubsection{Source identification}

To investigate the change of the contributions of LPG-fueled vehicles to VOCs and $\mathrm{NO}_{x}$, the online data of 15 VOCs and three trace gases at MK before (i.e., 8753 samples during October 2012-September 2013) and during the intervention program (i.e., 5833 samples during October 2013May 2014) were separately applied to PMF for source apportionments. It is noteworthy that the whole-air ambient concentrations of VOCs and trace gases, rather than those with the backgrounds deducted were used here, in order to keep consistency with the simulations of whole-air ambient $\mathrm{O}_{3}$ and photochemical reactivity. Figure 6 shows the source profiles of the four factors that best reproduced the concentrations of the input species before and during the intervention program, respectively. The first factor had high loadings of $\mathrm{C}_{3}-\mathrm{C}_{5}$ hydrocarbons and toluene, and was dominated by $\mathrm{CO}, \mathrm{NO}$ and $\mathrm{NO}_{2}$, which are all main components of vehicle exhaust (Guo et al., 2011a; Ho et al., 2009). The $n / i$ pentanes and toluene indicated emissions from gasoline vehicles, while the high $\mathrm{NO}_{x}$ loading was a signature of diesel exhaust. Since propane and $n / i$-butanes were not prominent, this factor was assigned as gasoline and diesel-fueled vehicle exhaust. Factor 2 was closely associated with LPG-fueled vehicle exhaust, with the dominance of propane, $n / i$-butanes and propene, the major components and combustion product of LPG (Guo et al., 2011b; Blake and Rowland, 1995). Factor 3 was distinguished by $\mathrm{NO}_{2}$ and the long-lived species, i.e., ethane, ethyne, benzene and $\mathrm{CO}$. The long-lived species were the indicators of aged air masses, in which $\mathrm{NO}_{2}$ was accumulated due to photochemical reactions. Hence, this factor represented aged air masses. Indeed, this profile highly coincided with the aged air in Hong Kong identified by Lau et al. (2010). The last factor explained most of the TEX compounds (toluene / ethylbenzene / xylenes), the tracers of solvent usage (Guo et al., 2007; Borbon et al., 2002). Therefore, factor 4 was identified as solvent usage.

\subsubsection{Source contribution}

Based on the VOC loadings in each source, Table 6 summarizes the mass and percentage contributions of the sources to VOCs at MK. LPG-fueled vehicle exhaust was the greatest contributor to VOCs at MK, with the mass contribution of $114.2 \pm 0.1 \mu \mathrm{g} \mathrm{m}^{-3}(51.51 \pm 0.05 \%)$ and $64.8 \pm 0.1 \mu \mathrm{g} \mathrm{m}^{-3}$ $(39.07 \pm 0.05 \%)$ before and during the program, respectively. These contributions were higher than those quantified at other sites in Hong Kong, i.e., suburban TC $(32.6 \pm 5.8 \%)$ (Ou et al., 2015), urban site Tsuen Wan (TW) $(21 \pm 2 \%)$ (Ling and Guo, 2014) and suburban YL (15\%) (Guo et al., 2007). It is noteworthy that factors such as study period, chemical species, source profiles and models used all influence the source apportionment. Bearing these factors in mind, the higher contributions of LPG-fueled vehicle exhaust in this study were likely due to the fact that MK was a roadside site closer to the emission sources. On the other hand, though gasoline/diesel vehicles emitted considerable VOCs (i.e., $60.5 \pm 0.1$ and $56.8 \pm 0.2 \mu \mathrm{g} \mathrm{m}^{-3}$ before and during the program, respectively), they were significantly lower than those emitted by LPG-fueled vehicles $(p<0.05)$, particularly before the replacement of the catalytic converters. While LPG-fueled vehicles only accounted for a small number of the registered vehicles $(\sim 3.1 \%)$ in Hong Kong (Table S4 in the Supplement), it was not unreasonable that LPG 

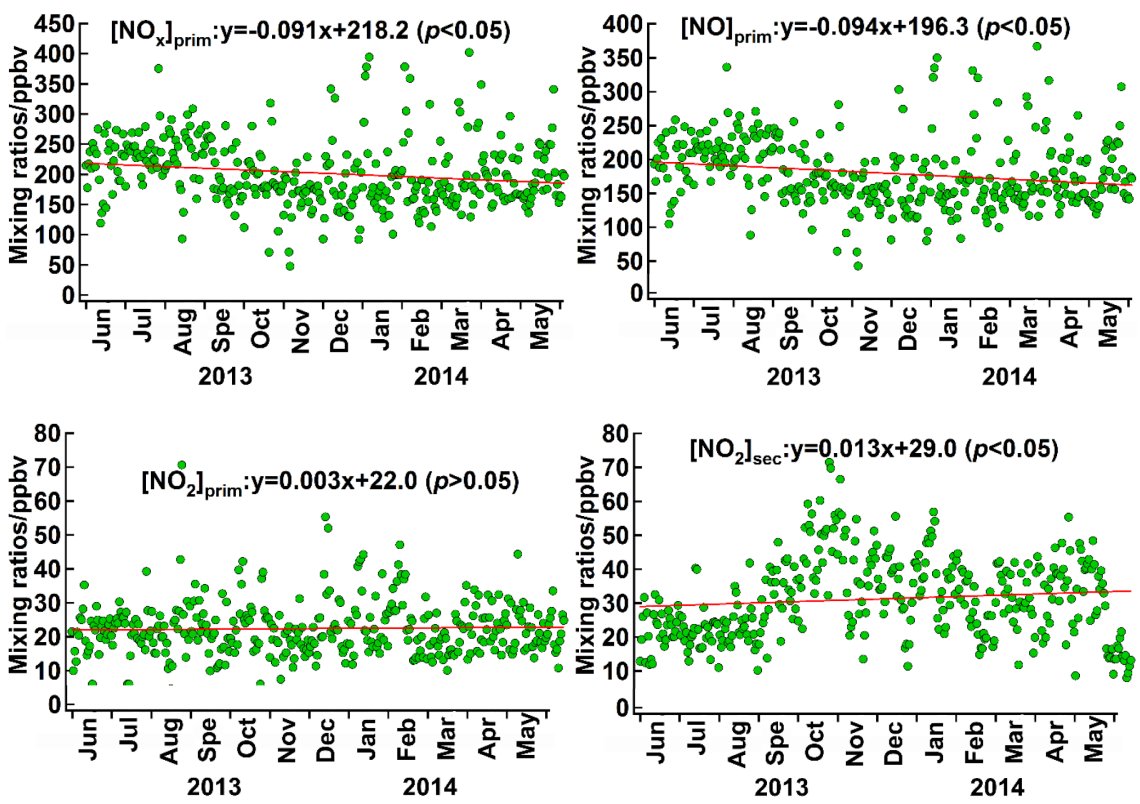

Figure 5. Variation trends of the daily average primary $\mathrm{NO}_{x}, \mathrm{NO}$ and $\mathrm{NO}_{2}$ and secondary $\mathrm{NO}_{2}$ at $\mathrm{MK}$ from June 2013 to May 2014 . In the equation label $x$ has a unit of days.

Table 5. Changing rates of primary $\mathrm{NO}_{x}, \mathrm{NO}, \mathrm{NO}_{2}$ and secondary $\mathrm{NO}_{2}\left(\right.$ ppbv day $\left.{ }^{-1}\right)$.

\begin{tabular}{llrrr}
\hline Site & Species & Jun 2011-May 2012 & Jun 2012-May 2013 & Jun 2013-May 2014 \\
\hline \multirow{2}{*}{ MK } & {$\left[\mathrm{NO}_{x}\right]_{\text {prim }}$} & -0.004 & $0.040^{*}$ & $\mathbf{- 0 . 0 9 1}$ \\
& {$[\mathrm{NO}]_{\text {prim }}$} & $0.004^{*}$ & 0.053 & $\mathbf{- 0 . 0 9 4}$ \\
& {$\left[\mathrm{NO}_{2}\right]_{\text {prim }}$} & $0.008^{*}$ & -0.013 & $\mathbf{0 . 0 0 3}$ \\
& {$\left[\mathrm{NO}_{2}\right]_{\text {sec }}$} & 0.020 & $-0.002^{*}$ & $\mathbf{0 . 0 1 3}$ \\
\hline $\mathrm{CWB}$ & {$\left[\mathrm{NO}_{x}\right]_{\text {prim }}$} & $-0.055^{*}$ & $0.089^{*}$ & $\mathbf{- 0 . 1 2 1}$ \\
& {$[\mathrm{NO}]_{\text {prim }}$} & $-0.048^{*}$ & $0.081^{*}$ & $\mathbf{- 0 . 1 2 7}$ \\
& {$\left[\mathrm{NO}_{2}\right]_{\text {prim }}$} & $-0.010^{*}$ & $0.004^{*}$ & $\mathbf{0 . 0 0 6}$ \\
& {$\left[\mathrm{NO}_{2}\right]_{\text {sec }}$} & 0.014 & $-0.001^{*}$ & $\mathbf{0 . 0 0 6}$ \\
\hline \multirow{2}{*}{ Central } & {$\left[\mathrm{NO}_{x}\right]_{\text {prim }}$} & $-0.041^{*}$ & 0.180 & $\mathbf{- 0 . 1 8 7}$ \\
& {$\left[\mathrm{NO}_{\text {prim }}\right.$} & $-0.045^{*}$ & 0.161 & $\mathbf{- 0 . 1 8 8}$ \\
& {$\left[\mathrm{NO}_{2}\right]_{\text {prim }}$} & $0.005^{*}$ & 0.018 & $\mathbf{0 . 0 0 2}$ \\
& {$\left[\mathrm{NO}_{2}\right]_{\text {sec }}$} & $0.011^{*}$ & $-0.004^{*}$ & $\mathbf{- 0 . 0 0 1}$ \\
\hline
\end{tabular}

* The changing rate is insignificant $(p>0.05)$; the bold numbers are changing rates during the implementation of the program.

made the highest contribution to VOCs, in view of low vapor pressure of the LPG component and high-density flow of the LPG-fueled vehicles at MK. Apart from vehicular exhaust, the aged VOCs and solvent usage also contributed $\sim 24 \%$ to VOCs at MK.

Table 7 lists the reduction of individual species from LPGfueled vehicles due to the intervention program. Propane (before: $21.15 \pm 0.02 \mu \mathrm{g} \mathrm{m}^{-3}$; during: $12.53 \pm 0.01 \mu \mathrm{g} \mathrm{m}^{-3}$ ), $n$-butane (before: $57.96 \pm 0.01 \mathrm{~g} \mathrm{~m}^{-3}$; during: $30.27 \pm$ $0.02 \mu \mathrm{g} \mathrm{m}^{-3}$ ) and $i$-butane (before: $27.20 \pm 0.02 \mu \mathrm{g} \mathrm{m}^{-3}$; during: $17.50 \pm 0.01 \mathrm{\mu g} \mathrm{m}^{-3}$ ) all decreased remarkably throughout the study period $(p<0.05)$. Meanwhile, the concentrations of $\mathrm{CO}$ and $\mathrm{NO}$ were also reduced from $248.4 \pm 1.3$ and $18.2 \pm 0.1 \mu \mathrm{g} \mathrm{m}^{-3}$ to $228.9 \pm 0.6$ and $2.08 \pm 0.04 \mathrm{\mu g} \mathrm{m}^{-3}$, respectively. However, $\mathrm{NO}_{2}$ apportioned in LPG exhaust was extremely minor (i.e., $0.6 \pm 0.2 \mu \mathrm{g} \mathrm{m}^{-3}$ and nil before and during the program, respectively), which might explain the insignificant decrease or even increase of $\mathrm{NO}_{2}$. During the study period, the LPGrelated VOCs and NO increased by $\sim 1.4$ and $\sim 2.9 \mu \mathrm{g} \mathrm{m}^{-3}$, respectively, at the background site, only respectively accounting for $3.0 \%$ and $1.3 \%$ of the decreased LPG-related VOCs $\left(\sim 46.1 \mu \mathrm{g} \mathrm{m}^{-3}\right)$ and NO $\left(\sim 226.8 \mu \mathrm{g} \mathrm{m}^{-3}\right)$ in LPGfueled vehicle exhaust. Therefore, it is believed that the re- 


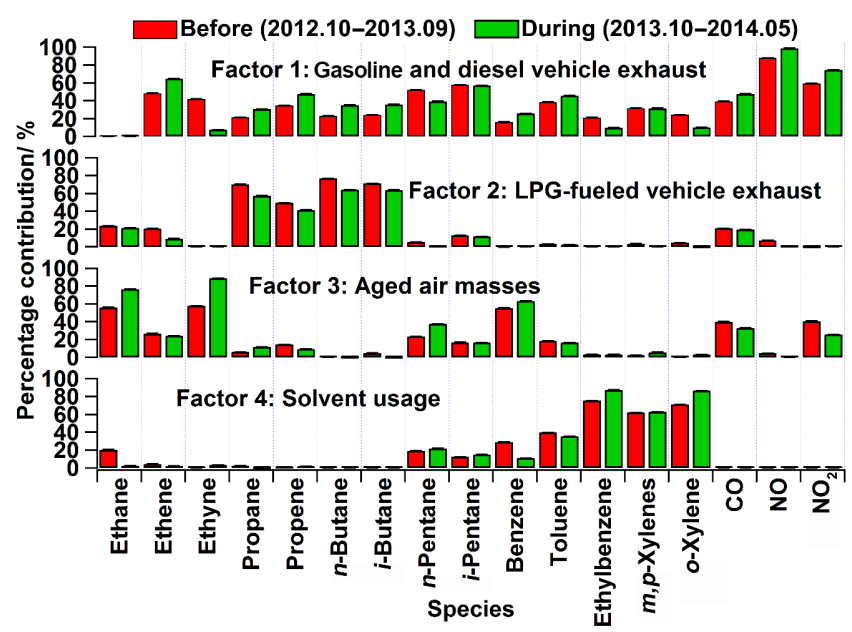

Figure 6. Source profiles resolved by PMF before (red bar) and during (green bar) the program. The standard errors are estimated with the bootstrap method in the model.

ductions of VOCs and NO in LPG-fueled vehicle exhaust benefited from the intervention program.

\subsection{Impact of the intervention program on $\mathrm{O}_{3}$ production}

\subsection{1 $\mathrm{O}_{3}$ simulation}

As VOCs and $\mathrm{NO}_{x}$ are key $\mathrm{O}_{3}$ precursors, it is essential to examine the impact of the reduction of VOCs and $\mathrm{NO}_{x}$ during the program on the $\mathrm{O}_{3}$ production. Figure 7 compares the observed and simulated $\mathrm{O}_{3}$ during daytime (07:00-19:00 local time (LT)) in the base case.

To quantitatively evaluate the performance of the model, the index of agreement (IOA) was introduced to test the agreement between the simulated and observed $\mathrm{O}_{3}$. Ranging from 0 to 1 , higher values of IOA indicate better agreement between the simulation and observation. The IOA was calculated using Eq. (10) (Huang et al., 2005):

$$
\mathrm{IOA}=1-\frac{\sum_{i=1}^{n}\left(O_{i}-S_{i}\right)^{2}}{\sum_{1=1}^{n}\left(\left|O_{i}-\bar{O}\right|+\left|S_{i}-\bar{O}\right|\right)^{2}},
$$

where $O_{i}$ and $S_{i}$ are the hourly observed and simulated values, and $\bar{O}$ represents the average of observations. In this study, the IOA reached 0.75 , and the accuracy of the simulation was $16.7 \pm 2.1 \%$, suggesting good performance of the model in $\mathrm{O}_{3}$ simulation. Bearing in mind the uncertainty of the model, the good agreement between the simulated and observed $\mathrm{O}_{3}$ implied a minor regional contribution at this roadside site.

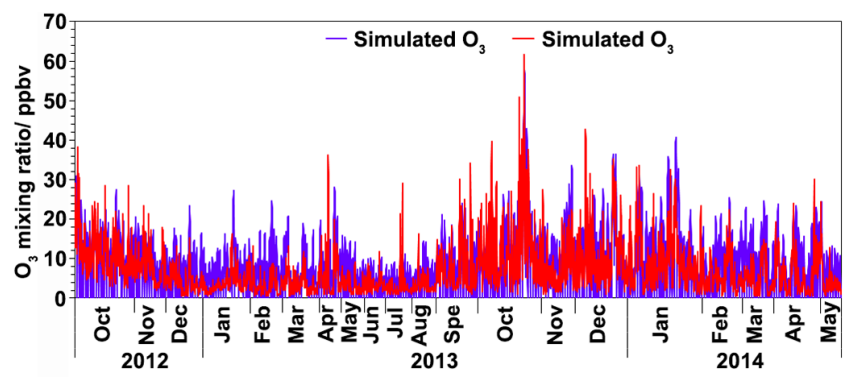

Figure 7. Hourly simulated and observed $\mathrm{O}_{3}$ during daytime hours (07:00-19:00 LT) at MK.

\subsubsection{Net $\mathrm{O}_{3}$ production}

Figure 8 shows the net $\mathrm{O}_{3}$ variations induced by VOCs, $\mathrm{NO}_{x}$ and VOCs $+\mathrm{NO}_{x}$ in LPG-fueled vehicle exhaust before and during the program. From before to during the intervention program, the daily average $\mathrm{O}_{3}$ variation induced by VOCs decreased significantly $(p<0.05)$, with a rate of $-9.3 \times 10^{-5} \mathrm{ppbv} \mathrm{day}^{-1}$, whereas $\mathrm{O}_{3}$ increased significantly at a rate of $1.3 \times 10^{-3} \mathrm{ppbv}^{-1} \mathrm{yay}^{-1}$ due to the reduction of $\mathrm{NO}_{x}$ titration $(p<0.01)$. As a result, the net contribution to $\mathrm{O}_{3}$ made by the LPG-fueled vehicle exhaust increased $(p<0.01)$ from $-0.47 \pm 0.03$ ppbv before the program to $-0.06 \pm 0.02 \mathrm{ppbv}$ during the program, with a rate of $1.2 \times 10^{-3} \mathrm{ppbv}_{\text {day }}{ }^{-1}$; namely, $\mathrm{O}_{3}$ increased by $0.40 \pm 0.03 \mathrm{ppbv}, \sim 5.6 \%$ of the observed $\mathrm{O}_{3}$ at $\mathrm{MK}$ $(7.14 \pm 0.21 \mathrm{ppbv})$. The simulation results for the scenarios with and without the input of background concentrations indicated minor contribution of background concentrations to $\mathrm{O}_{3}$ for both periods of before $(0.24 \mathrm{ppbv}$, accounting for $\sim 3.5 \%$ of measured average) and during ( $0.27 \mathrm{ppbv}$; $\sim 3.7 \%$ ) the program, suggesting the use of whole-air ambient concentrations without background subtraction for $\mathrm{O}_{3}$ simulation was appropriate. The slight increase of $\mathrm{O}_{3}$ $(\sim 0.03 \mathrm{ppbv})$ caused by the background variations of $\mathrm{O}_{3}$ precursors from period before the program to during the program constituted only $\sim 7.5 \%$ of the $\mathrm{O}_{3}$ enhancement $(0.40 \pm 0.03 \mathrm{ppbv})$ due to the replacement program, further confirming a negligible impact of the background on the assessment of the program. It is noteworthy that the increase was not a sudden change in reality, but was caused by the segmentation of source apportionment (i.e., October 2012 September 2013 and October 2013-May 2014). Indeed, the measurement data also revealed an increasing $\mathrm{O}_{3}$ trend from October 2012 to May 2014, with a rate of 3.3 pptv day $^{-1}$ $(p<0.05)$, higher than the $\mathrm{O}_{3}$ increase caused by LPG. This discrepancy might be related to the $\mathrm{O}_{3}$ production by other sources and/or other mechanisms not considered in the above simulations, e.g., alkyl nitrate $\left(\mathrm{RONO}_{2}\right)$ chemistry. 
Table 6. Mass concentration and percentage contribution of the four sources to VOCs at MK before and during the program.

\begin{tabular}{lrrrr}
\hline Source & \multicolumn{2}{c}{ Before } & \multicolumn{2}{c}{ During } \\
\cline { 2 - 5 } & Mass $\left(\mu \mathrm{g} \mathrm{m}^{-3}\right)$ & Percentage $(\%)$ & Mass $\left(\mu \mathrm{g} \mathrm{m}^{-3}\right)$ & Percentage $(\%)$ \\
\hline Gasoline/diesel vehicle exhaust & $60.5 \pm 0.1$ & $27.30 \pm 0.05$ & $56.8 \pm 0.2$ & $34.3 \pm 0.1$ \\
LPG-fueled vehicle exhaust & $114.2 \pm 0.1$ & $51.51 \pm 0.05$ & $64.8 \pm 0.1$ & $39.07 \pm 0.05$ \\
Aged air masses & $19.8 \pm 0.2$ & $8.9 \pm 0.1$ & $24.6 \pm 0.1$ & $14.8 \pm 0.1$ \\
Solvent usage & $27.30 \pm 0.04$ & $12.31 \pm 0.01$ & $19.6 \pm 0.1$ & $11.84 \pm 0.04$ \\
\hline
\end{tabular}

Table 7. VOCs and trace gases emitted from LPG-fueled vehicles before and during the intervention program (unit: $\mu \mathrm{g} \mathrm{m}^{-3}$ unless otherwise specified). The standard errors are estimated with the bootstrap method in the PMF model. The bold fonts demonstrate significant reductions of LPG related VOCs and $\mathrm{NO}_{x}$.

\begin{tabular}{lrr}
\hline & Before & During \\
\hline Ethane & $1.192 \pm 0.001$ & $1.19 \pm 0.01$ \\
Ethene & $1.327 \pm 0.005$ & $0.431 \pm 0.004$ \\
Ethyne & $0.0000 \pm 0.0004$ & $0.000 \pm 0.001$ \\
Propane & $\mathbf{2 1 . 1 5} \pm \mathbf{0 . 0 2}$ & $\mathbf{1 2 . 5 3} \pm \mathbf{0 . 0 1}$ \\
Propene & $\mathbf{2 . 8 6 0} \pm \mathbf{0 . 0 0 4}$ & $\mathbf{1 . 5 5 3} \pm \mathbf{0 . 0 0 1}$ \\
$n$-butane & $\mathbf{5 7 . 9 6} \pm \mathbf{0 . 0 1}$ & $\mathbf{3 0 . 2 7} \pm \mathbf{0 . 0 2}$ \\
$i$-butane & $\mathbf{2 7 . 2 0} \pm \mathbf{0 . 0 2}$ & $\mathbf{1 7 . 5 0} \pm \mathbf{0 . 0 1}$ \\
$n$-pentane & $0.251 \pm 0.003$ & $0.039 \pm 0.002$ \\
$i$-pentane & $1.04 \pm 0.01$ & $0.786 \pm 0.002$ \\
Benzene & $0.00 \pm 0.01$ & $0.000 \pm 0.001$ \\
Toluene & $0.66 \pm 0.02$ & $0.50 \pm 0.01$ \\
Ethylbenzene & $0.000 \pm 0.001$ & $0.000 \pm 0.004$ \\
$m, p$-xylene & $0.416 \pm 0.003$ & $0.00 \pm 0.01$ \\
$o$-xylene & $0.144 \pm 0.001$ & $0.006 \pm 0.001$ \\
CO & $248.4 \pm 1.3$ & $228.9 \pm 0.6$ \\
NO & $\mathbf{1 8 . 2} \pm \mathbf{0 . 1}$ & $\mathbf{2 . 0 8} \pm \mathbf{0 . 0 4}$ \\
NO 2 & $\mathbf{0 . 6} \pm \mathbf{0 . 2}$ & $\mathbf{0 . 0 0} \pm \mathbf{0 . 0 8}$ \\
Sum of VOCs & $114.2 \pm 0.1$ & $64.8 \pm 0.1$ \\
Contribution to VOCs $(\%)$ & $51.5 \pm 0.1$ & $39.1 \pm 0.1$ \\
\hline
\end{tabular}

\subsection{Photochemical reactivity}

\subsubsection{OH, $\mathrm{HO}_{2}$ and their formation/loss rates in whole air}

As the "detergent" of atmosphere, $\mathrm{OH}$ initiates the oxidation of air pollutants including VOCs, $\mathrm{CO}$ and $\mathrm{NO}_{x}$, leading to $\mathrm{O}_{3}$ formation, and the cycling between $\mathrm{OH}$ and $\mathrm{HO}_{2}$ accelerates the propagation of the chain reactions. Thus, the budget of $\mathrm{OH}$ and $\mathrm{HO}_{2}$ is an important parameter of a photochemical system. Figure 9 presents the average daytime patterns of $\mathrm{OH}$ and $\mathrm{HO}_{2}$ before and during the program. Typical bellshaped patterns were observed for $\mathrm{OH}$ and $\mathrm{HO}_{2}$, which increased from morning to noon, peaked at 12:00-13:00 and then decreased to low levels in the afternoon.

The average simulated concentrations of $\mathrm{OH}$ and $\mathrm{HO}_{2}$ were $1.64 \pm 0.78 \times 10^{5}$ and $2.49 \pm 1.28 \times 10^{5}$ molecules $\mathrm{cm}^{-3}$ before the program, and

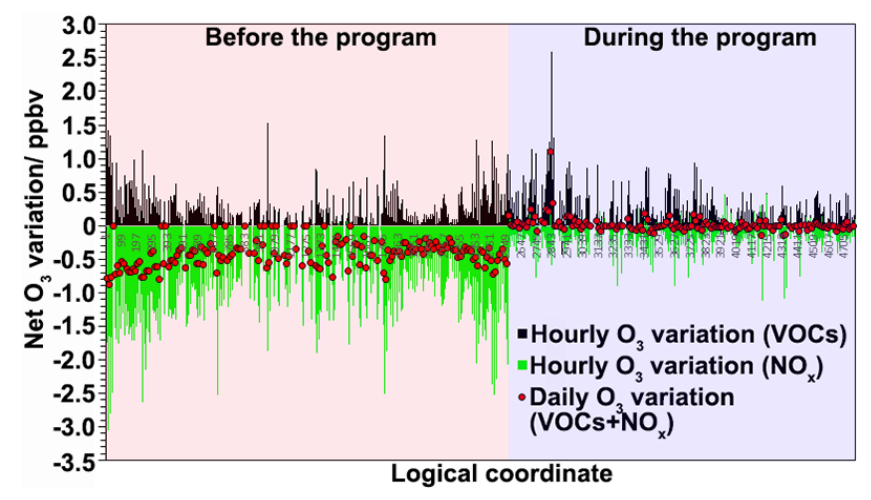

Figure 8. $\mathrm{Net}_{3}$ variation as a function of VOCs, $\mathrm{NO}_{x}$ and VOCs $+\mathrm{NO}_{x}$ emitted from LPG-fueled vehicles.

$1.80 \pm 0.85 \times 10^{5}$ and $4.18 \pm 2.03 \times 10^{5}$ molecules $\mathrm{cm}^{-3}$ during the program, respectively. Compared to those modeled at an urban site in Hong Kong $\left(2.3-3.6 \times 10^{6}\right.$ molecules $\mathrm{cm}^{-3}$ for $\mathrm{OH}$ and 3.4$4.4 \times 10^{8}$ molecules $\mathrm{cm}^{-3}$ for $\mathrm{HO}_{2}$ ) (Ling et al., 2014), and those measured at a VOC-rich site in PRD $\left(15 \times 10^{6}\right.$ and $18 \times 10^{8}$ molecules $\mathrm{cm}^{-3}$ for $\mathrm{OH}$ and $\mathrm{HO}_{2}$, respectively) ( $\mathrm{Lu}$ et al., 2012; Lou et al., 2010), the $\mathrm{OH}$ and $\mathrm{HO}_{2}$ levels were much lower at $\mathrm{MK}$. This is not surprising because much $\mathrm{OH}$ and $\mathrm{HO}_{2}$ were consumed by high levels of VOCs and $\mathrm{NO}_{x}$ at the roadside MK (Fig. S3 in the Supplementary material shows the simulated $\mathrm{OH}$ and $\mathrm{HO}_{2}$ at different sites with the PBM-MCM model). In addition, this study covered different seasons of the study years, rather than the $\mathrm{O}_{3}$ episodes in Ling et al. (2014) and summer only in Lu et al. (2012) and Lou et al. (2010) when photochemical reactivity was usually stronger. Apart from the increase of $\mathrm{OH}$ and $\mathrm{HO}_{2}$ from the period before the program to during the program, the ratio of $\mathrm{HO}_{2} / \mathrm{OH}$ was significantly higher during the program (i.e., $3.7 \pm 0.5)$ than that before (i.e., $1.9 \pm 0.3)(p<0.05)$, which might partly explain the increase of $\mathrm{O}_{3}$ throughout the study period. Nevertheless, since the $\mathrm{OH}, \mathrm{HO}_{2}$ and $\mathrm{HO}_{2} / \mathrm{OH}$ were simulated using the whole-air concentrations of $\mathrm{O}_{3}$ precursors, whether their increases were mainly caused by the intervention program requires further investigation, as shown below.

Since the changes in the formation/loss rates from the period before the program to during the program 

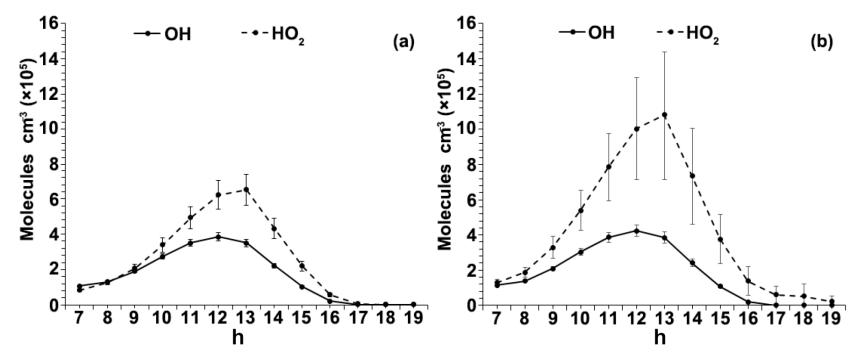

Figure 9. Daytime patterns of $\mathrm{OH}$ and $\mathrm{HO}_{2}$ (a) before and (b) during the program.
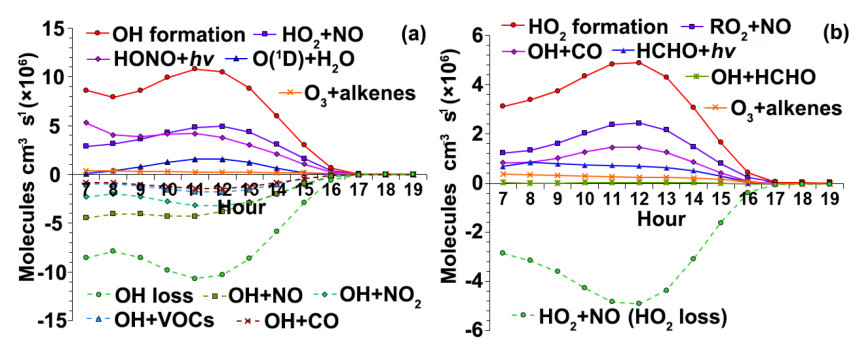

Figure 10. Average formation and loss pathways of $\mathrm{OH}$ and $\mathrm{HO}_{2}$ at MK during the study period.

were minor for each pathway of $\mathrm{OH}$ and $\mathrm{HO}_{2}$, Fig. 10 presents their average pathway-specific formation and loss rates over the whole study period. The total formation/loss rates of $\mathrm{OH}$ and $\mathrm{HO}_{2}$ were $5.8 \pm 2.4 \times 10^{6}$ and $2.6 \pm 1.0 \times 10^{6}$ molecules $\mathrm{cm}^{-3} \mathrm{~s}^{-1}$, respectively. The reaction of $\mathrm{HO}_{2}$ with $\mathrm{NO}, \mathrm{HONO}$ photolysis, $\mathrm{O}_{3}$ photolysis and ozonolysis of alkenes were the main sources of $\mathrm{OH}$, with contributions of $56.7 \pm 11.6,31.7 \pm 10.7,6.6 \pm 3.3$ and $5.0 \pm 1.7 \%$, respectively. On the other hand, $\mathrm{OH}$ was consumed by reaction with $\mathrm{NO}(36.5 \pm 5.5 \%), \mathrm{NO}_{2}$ $(35.1 \pm 4.6 \%)$, VOCs $(14.8 \pm 1.2 \%)$ and $\mathrm{CO}(13.6 \pm 1.0 \%)$. For $\mathrm{HO}_{2}$ formation, the reaction between $\mathrm{RO}_{2}$ and $\mathrm{NO}$ was the most predominant pathway $(54.8 \pm 8.8 \%)$, followed by the reaction of $\mathrm{OH}$ with $\mathrm{CO}(23.3 \pm 3.9 \%)$, HCHO photolysis $(13.1 \pm 4.6 \%)$, ozonolysis of alkenes $(7.9 \pm 2.1 \%)$ and the reaction of $\mathrm{OH}$ with $\mathrm{HCHO}(0.8 \pm 0.2 \%)$. Meanwhile, $\mathrm{HO}_{2}$ was almost exclusively consumed by reacting with NO.

\subsubsection{Influence of the program on photochemical reactivity}

The differences between the simulation outputs of the scenarios with and without LPG VOCs and $\mathrm{NO}_{x}$ inputs determined the contributions of LPG-fueled vehicle exhaust to the formation/loss rates of $\mathrm{OH}$ and $\mathrm{HO}_{2}$, as summarized in Table 8. Generally, the formation/loss rates of $\mathrm{OH}$ and $\mathrm{HO}_{2}$ contributed by the LPG source decreased from the period before the program to during the program, which was caused by the reduction of VOCs and $\mathrm{NO}_{x}$ in the LPG source. Furthermore, since the sum of the formation rates was lower than the
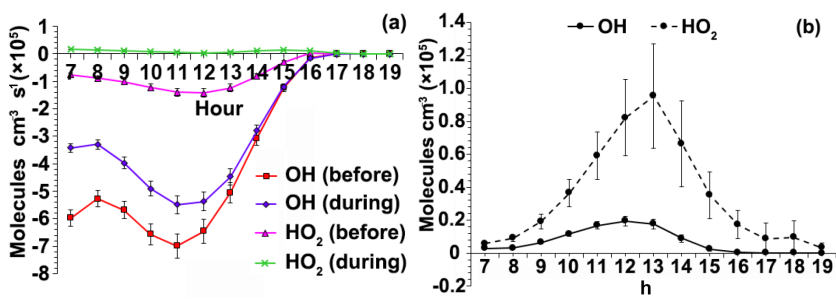

Figure 11. (a) Net production of $\mathrm{OH}$ and $\mathrm{HO}_{2}$ by LPG-fueled vehicle exhaust (negative values indicate net destruction); and (b) increases of $\mathrm{OH}$ and $\mathrm{HO}_{2}$ from the period before the program to during the program.

loss rates for $\mathrm{OH}$ for both before and during the program, but for only $\mathrm{HO}_{2}$ before the program, the net effects of the LPG source to $\mathrm{OH}$ and $\mathrm{HO}_{2}$ were destructive. However, the $\mathrm{HO}_{2}$ formation rate exceeded its loss rate for the period of during the program, indicating a net production of $\mathrm{HO}_{2}$ by the $\mathrm{LPG}$ source.

Figure 11a shows the net effects of the LPG source on the production of $\mathrm{OH}$ and $\mathrm{HO}_{2}$. From before to during the program, the destruction rate of $\mathrm{OH}$ decreased, while the destruction of $\mathrm{HO}_{2}$ switched to production. These variations led to the increases of $\mathrm{OH}$ and $\mathrm{HO}_{2}$ from the period before the program to during the program, as shown in Fig. 11b. Different from the increases of $\mathrm{OH}$ and $\mathrm{HO}_{2}$ in the whole air as shown in Fig. 9, the increases here were caused by the intervention program. The $\mathrm{OH}$ and $\mathrm{HO}_{2}$ levels increased by $6.9 \pm 1.1 \times 10^{3}$ molecules $\mathrm{cm}^{-3}$ and $3.4 \pm 1.2 \times 10^{4}$ molecules $\mathrm{cm}^{-3}$, respectively. The higher increase of $\mathrm{HO}_{2}$ than $\mathrm{OH}$ led to a higher ratio of $\mathrm{HO}_{2} / \mathrm{OH}$ during the program, resulting in a consequent $\mathrm{O}_{3}$ increment.

\subsection{Improvement of the intervention program}

\subsection{1 $\mathrm{O}_{3}-\mathrm{VOCs}^{-}-\mathrm{NO}_{x}$ sensitivity in the whole air}

$\mathrm{O}_{3}-$ VOCs $-\mathrm{NO}_{x}$ sensitivity can reflect the $\mathrm{O}_{3}$ variation relative to the change of VOCs and $\mathrm{NO}_{x}$, from which VOClimited regimes and $\mathrm{NO}_{x}$-limited regimes in $\mathrm{O}_{3}$ formation can be indicated. Figure $12 \mathrm{a}$ and $\mathrm{b}$ show the $\mathrm{O}_{3}-\mathrm{VOCs}-$ $\mathrm{NO}_{x}$ sensitivity in the air at MK between 40 and 100 and 0.5 and $40 \%$ of the observed average $\mathrm{NO}_{x}$, respectively. The ranges were selected according to the $\mathrm{O}_{3}$ levels and behaviors responding to the variations of VOCs and $\mathrm{NO}_{x}$ (details were given below). This sensitivity diagram was obtained with the aid of the PBM-MCM model, and based on the average diurnal profiles of air pollutants in the atmosphere before the intervention program. The abscissa and longitudinal coordinates represent the percentages of $\mathrm{NO}_{x}$ and VOCs relative to the real average values measured at MK (i.e., $100 \% \mathrm{NO}_{x}=235.6 \mathrm{ppbv} ; 100 \% \mathrm{VOCs}=51.2 \mathrm{ppbv}$ ). In other words, they reflect the reduction percentages. For example, $80 \% \mathrm{NO}_{x}$ or VOCs means $\mathrm{NO}_{x}$ or VOCs was cut 
Table 8. Contributions of LPG-fueled vehicle exhaust to the formation and loss of $\mathrm{OH}$ and $\mathrm{HO}_{2}$ before and during the program. The bold fonts demonstrate the sum of $\mathrm{OH} / \mathrm{HO} 2$ formation/loss rates or the net formation rate of $\mathrm{OH} / \mathrm{HO}_{2}$.

\begin{tabular}{|c|c|c|c|}
\hline & Reaction & $\begin{array}{l}\text { Before } \\
\left(\text { molecules } \mathrm{cm}^{-3} \mathrm{~s}^{-1}\right)\end{array}$ & $\begin{array}{l}\text { During } \\
\text { (molecules } \mathrm{cm}^{-3} \mathrm{~s}^{-1} \text { ) }\end{array}$ \\
\hline $\mathrm{OH}$ formation & $\begin{array}{l}\mathrm{HO}_{2}+\mathrm{NO} \\
\mathrm{O}_{3}+\text { alkenes } \\
\text { Sum of } \mathrm{OH} \text { formation }\end{array}$ & $\begin{array}{l}(1.8 \pm 0.8) \times 10^{5} \\
(3.3 \pm 1.2) \times 10^{4} \\
(\mathbf{2 . 2} \pm \mathbf{0 . 9}) \times \mathbf{1 0}^{5}\end{array}$ & $\begin{array}{l}(2.8 \pm 1.2) \times 10^{4} \\
(3.1 \pm 1.2) \times 10^{4} \\
(\mathbf{5 . 2} \pm \mathbf{1 . 9}) \times \mathbf{1 0}^{4}\end{array}$ \\
\hline $\mathrm{OH}$ loss & $\begin{array}{l}\mathrm{OH}+\mathrm{CO} \\
\mathrm{OH}+\mathrm{NO}_{2} \\
\mathrm{OH}+\mathrm{NO} \\
\mathrm{OH}+\mathrm{VOCs} \\
\text { Sum of OH loss }\end{array}$ & $\begin{array}{l}(1.4 \pm 0.6) \times 10^{4} \\
(5.0 \pm 2.0) \times 10^{3} \\
(1.9 \pm 0.02) \times 10^{5} \\
(2.3 \pm 0.02) \times 10^{5} \\
(\mathbf{5 . 7} \pm \mathbf{1 . 6}) \times \mathbf{1 0}^{\mathbf{5}}\end{array}$ & $\begin{array}{l}(1.5 \pm 0.6) \times 10^{5} \\
- \\
(2.4 \pm 1.0) \times 10^{4} \\
(1.5 \pm 0.6) \times 10^{5} \\
(\mathbf{3 . 2} \pm \mathbf{1 . 4}) \times \mathbf{1 0}^{5}\end{array}$ \\
\hline \multicolumn{2}{|c|}{ Net OH formation } & $-(3.6 \pm 0.8) \times 10^{5}$ & $-(2.7 \pm 1.2) \times 10^{5}$ \\
\hline $\mathrm{HO}_{2}$ formation & $\begin{array}{l}\mathrm{RO}_{2}+\mathrm{NO} \\
\mathrm{O}_{3}+\text { alkenes } \\
\text { Sum of } \mathrm{HO}_{2} \text { formation }\end{array}$ & $\begin{array}{l}(8.1 \pm 3.4) \times 10^{4} \\
(3.3 \pm 1.2) \times 10^{4} \\
(\mathbf{1 . 1} \pm \mathbf{0 . 4}) \times \mathbf{1 0}^{\mathbf{5}}\end{array}$ & $\begin{array}{l}(1.3 \pm 0.5) \times 10^{4} \\
(3.1 \pm 1.2) \times 10^{4} \\
(\mathbf{3 . 6} \pm \mathbf{1 . 3}) \times \mathbf{1 0}^{4}\end{array}$ \\
\hline $\mathrm{HO}_{2}$ loss & $\begin{array}{l}\mathrm{HO}_{2}+\mathrm{NO} \\
\text { Sum of } \mathbf{H O}_{2} \text { loss }\end{array}$ & $\begin{array}{l}(1.8 \pm 0.8) \times 10^{5} \\
(\mathbf{1 . 8} \pm \mathbf{0 . 8}) \times \mathbf{1 0}^{\mathbf{5}}\end{array}$ & $\begin{array}{l}(2.8 \pm 1.2) \times 10^{4} \\
(\mathbf{2 . 8} \pm \mathbf{1 . 2}) \times \mathbf{1 0}^{4}\end{array}$ \\
\hline Net $\mathrm{HO}_{2}$ forma & & $-(7.0 \pm 3.1) \times 10^{4}$ & $(7.8 \pm 3.1) \times 10^{3}$ \\
\hline
\end{tabular}

by $20 \% . \mathrm{O}_{3}$ was simulated in 220 cases (i.e., 10 VOCs $\times 22$ $\mathrm{NO}_{x}$ ), and the maximum $\mathrm{O}_{3}$ in each case was extracted.

It was found that within the cutting range of $0-60 \%$ of $\mathrm{NO}_{x}$ (Fig. 12a), $\mathrm{O}_{3}$ increased with the increase of VOCs and the decrease of $\mathrm{NO}_{x}$, indicating a VOC-limited regime in $\mathrm{O}_{3}$ formation. The black curve, perpendicular to the isopleths of $\mathrm{O}_{3}$, demonstrated the most sensitive response of $\mathrm{O}_{3}$ to VOCs and $\mathrm{NO}_{x}$. Namely, $\mathrm{O}_{3}$ reduction could be achieved most efficiently towards the abscissa. Using the absolute value of RIR (i.e., $|\mathrm{RIR}|$ ) as a measure of the $\mathrm{O}_{3}-\mathrm{VOCs}-\mathrm{NO}_{x}$ sensitivity, it increased with the reduction of VOCs and $\mathrm{NO}_{x}$. For example, |RIR| for VOCs and $\mathrm{NO}_{x}$ increased from 0.09 and 0.22 in the scenario of $90 \%$ VOCs and $90 \% \mathrm{NO}_{x}$, to 0.25 and 0.90 in the scenario of $50 \%$ VOCs and $50 \% \mathrm{NO}_{x}$, respectively. From before to during the program, VOCs and $\mathrm{NO}_{x}$ decreased $\sim 12$ and $\sim 15 \%$, respectively (i.e., from point $\mathrm{A}$ to B), causing a slight $\mathrm{O}_{3}$ increment as described in Sect. 3.3.2. The red and green curves in the lower right corner of Fig. 12a show the $\mathrm{O}_{3}$ production as a function of VOCs cut before $\left(\mathrm{NO}_{x}=100 \%\right)$ and during the program $\left(\mathrm{NO}_{x}=\sim 85 \%\right)$, respectively. With the reduction of VOCs, $\mathrm{O}_{3}$ decreased. Since $\mathrm{O}_{3}-\mathrm{VOCs}-\mathrm{NO}_{x}$ sensitivity increased during the program, $\mathrm{O}_{3}$ decreased by 45.5 and $67.6 \mathrm{pptv}$ with $10 \%$ cut of VOCs before and during the program, respectively, which means that $\mathrm{O}_{3}$ reduction could be achieved more efficiently by further cutting VOCs during the program.

With the continuous reduction of $\mathrm{NO}_{x}$, it was expected that the $\mathrm{O}_{3}-\mathrm{VOCs}-\mathrm{NO}_{x}$ sensitivity might change substantially due to the dual role of $\mathrm{NO}_{x}$ in $\mathrm{O}_{3}$ formation and titration. Figure $12 \mathrm{~b}$ shows the $\mathrm{O}_{3}-\mathrm{VOCs}-\mathrm{NO}_{x}$ sensitivity in the cutting range of $60-99.5 \%$ of $\mathrm{NO}_{x}$. It is noticeable that in the cutting range of $\sim 60-89.5 \%$ of $\mathrm{NO}_{x}, \mathrm{O}_{3}$ increased with the increase of VOCs and decrease of $\mathrm{NO}_{x}$, similar to that in the cutting range of $0-60 \%$ of $\mathrm{NO}_{x}$. However, a transition area appeared when $\mathrm{NO}_{x}$ was further cut, where $\mathrm{O}_{3}$ stayed relatively stable with $\mathrm{NO}_{x}$ variations, and decreased with VOC reductions. This transition area changed from $\sim 5.5-10.5 \%$ (i.e., VOCs $=100 \%$ ) to $\sim 2.5-6 \%$ of $\mathrm{NO}_{x}$ (i.e., VOCs $=10 \%$ ). The appearance of the transition area implied that the titration of $\mathrm{O}_{3}$ by $\mathrm{NO}_{x}$ reached the minimum level, and further cutting of $\mathrm{NO}_{x}$ might actually cause $\mathrm{O}_{3}$ reduction. As expected, $\mathrm{O}_{3}$ decreased with the reduction of $\mathrm{NO}_{x}$ when $\mathrm{NO}_{x}$ was reduced to lower than $\sim 2.5-5.5 \%$ (i.e., $\sim 2.5 \%$ and $\sim 5.5 \%$ for $10 \%$ and $100 \%$ VOCs, respectively), and responded weakly to VOC variations. This means that $\mathrm{O}_{3}$ formation switched to a $\mathrm{NO}_{x}$-limited regime. It should be emphasized that this is the first attempt on the study of $\mathrm{O}_{3}-\mathrm{VOCs}-\mathrm{NO}_{x}$ sensitivity at roadsides in Hong Kong, which could be a reference for the formulation and implementation of future air pollution control strategies in Hong Kong. 

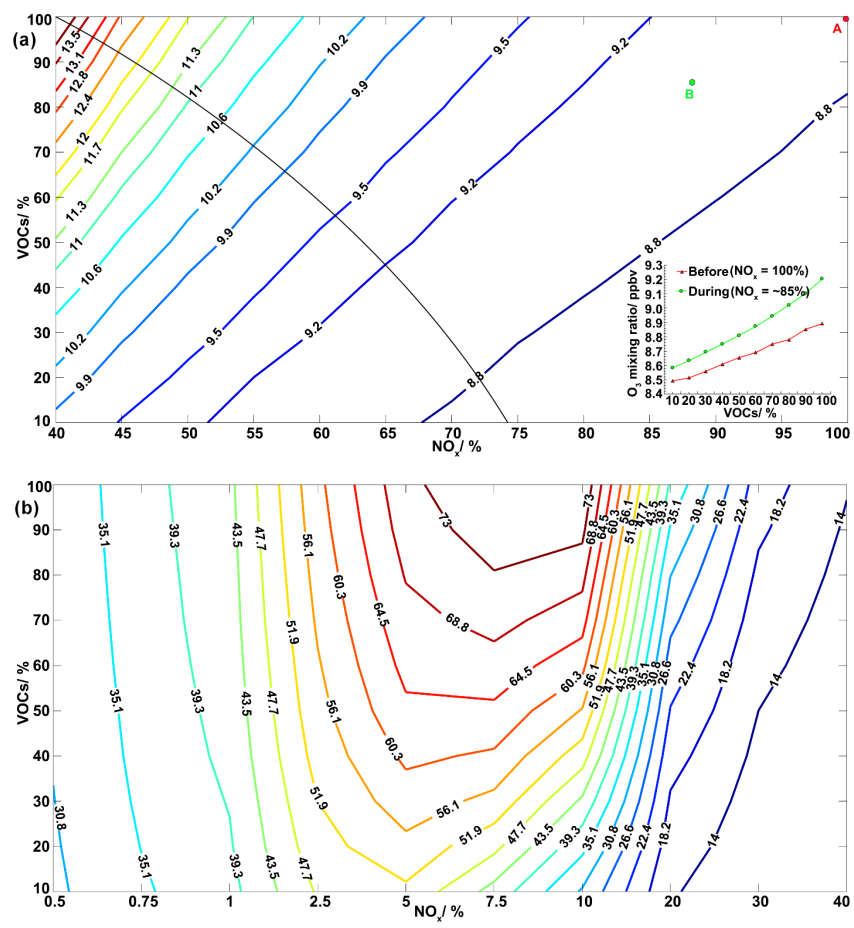

Figure 12. (a) $\mathrm{O}_{3}-\mathrm{VOCs}-\mathrm{NO}_{x}$ sensitivity within the cutting range of $0-60 \%$ of $\mathrm{NO}_{x}$. The black curve demonstrates the most sensitive response of $\mathrm{O}_{3}$ to VOCs and $\mathrm{NO}_{x}$. Points $\mathrm{A}$ and $\mathrm{B}$ represent the $\mathrm{O}_{3}-\mathrm{VOCs}-\mathrm{NO}_{x}$ relationship before and during the program, respectively. The red and green curves in the small legend show the $\mathrm{O}_{3}$ production as a function of VOC cuts before and during the program, respectively. (b) $\mathrm{O}_{3}-\mathrm{VOCs}-\mathrm{NO}_{x}$ sensitivity within the cutting range of $60-99.5 \%$ of $\mathrm{NO}_{x}$.

Table 9. RIR and RIR (weighted concentration) of LPG-related VOCs.

\begin{tabular}{lll}
\hline & $\begin{array}{l}\text { RIR } \\
\left(\% / \% \times 10^{-2}\right)\end{array}$ & $\begin{array}{l}\text { RIR } \\
(\text { weighted concentration }) \\
\left(\mu \mathrm{g} \mathrm{m}^{-3}\right)\end{array}$ \\
\hline Propane & 3.47 & 1.04 \\
Propene & 5.21 & 0.30 \\
$i$-butane & 3.47 & 1.33 \\
$n$-butane & 3.47 & 2.61 \\
\hline
\end{tabular}

\subsection{2 $\mathrm{O}_{3}-\mathrm{VOCs}^{-\mathrm{NO}_{x}}$ sensitivity in LPG}

Figure 13 shows the net $\mathrm{O}_{3}$ increment (i.e., positive and negative values indicate the increase and decrease of $\mathrm{O}_{3}$, respectively) as a response of the reduction of VOCs and $\mathrm{NO}_{x}$ in LPG-fueled vehicle exhaust. It was found that the net $\mathrm{O}_{3}$ increment uniformly increased with the increase of $\mathrm{NO}_{x}$ cut and the decrease of VOCs cut. To ensure that $\mathrm{O}_{3}$ would not increase during the program, the reduction of VOCs and $\mathrm{NO}_{x}$ should be within the highlighted area; that is, the highest cutting percentage of $\mathrm{NO}_{x}$ should be less than $68.9 \%$ (i.e., point

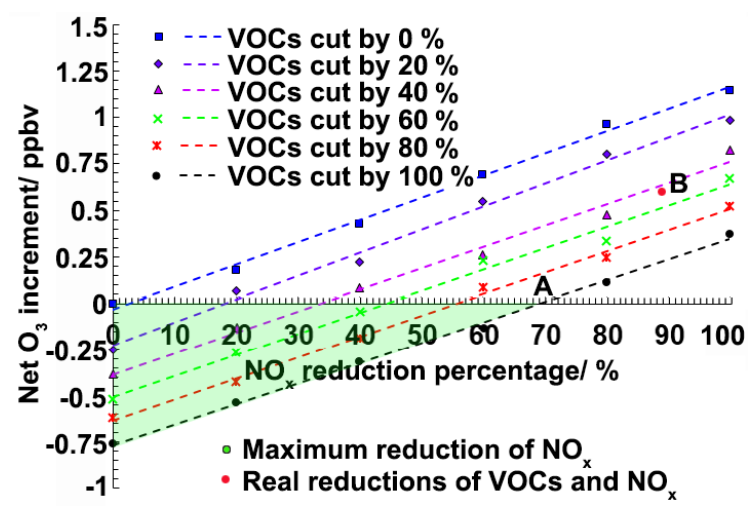

Figure 13. Net $\mathrm{O}_{3}$ increment as a function of the reduction percentages of VOCs and $\mathrm{NO}_{x}$ in LPG-fueled vehicle exhaust. The highlighted area indicates zero $\mathrm{O}_{3}$ increment.

A). Furthermore, when the cutting percentage of VOCs increased from 20 to $100 \%$, the maximum cutting percentage of $\mathrm{NO}_{x}$ for zero $\mathrm{O}_{3}$ increment was between 18.2 and $68.9 \%$, and the cutting ratio of VOCs $/ \mathrm{NO}_{x}$ increased from 1.1 to 1.45, suggesting that the cutting ratio of VOCs $/ \mathrm{NO}_{x}$ should be $>1.1$ in order to maintain zero $\mathrm{O}_{3}$ increment. During the program, VOCs and $\mathrm{NO}_{x}$ in LPG-fueled vehicle exhaust were cut by $\sim 43$ and $\sim 89 \%$ (i.e., point B), respectively. According to the cutting ratios of VOCs $/ \mathrm{NO}_{x}(\sim 1.45)$ in the high cutting range of $\mathrm{NO}_{x}$, the minimum reduction percentage of VOCs should be $\sim 129 \%$ when $\mathrm{NO}_{x}$ was cut by $89 \%$. In other words, $\mathrm{O}_{3}$ would inevitably increase in this case.

Indeed, $\mathrm{NO}_{2}$ experienced an overall increase from 1999 to 2013 at the roadsides in Hong Kong (HKEPD, 2014). According to this study, secondary $\mathrm{NO}_{2}$ might be more responsible for the increase. Considering nil emission of $\mathrm{NO}_{2}$ (Sect. 3.2.2) and low emission of NO from LPG usage (i.e., 4.0 and $1.1-7.3 \%$ based on the emission inventory and source apportionment, respectively), an alternative scheme was proposed; namely, reasonable cutting ratio of VOCs $/ \mathrm{NO}_{x}$ was used to fulfill zero $\mathrm{O}_{3}$ increase when VOC and $\mathrm{NO}_{x}$ were cut. Although the $\mathrm{O}_{3}$ production increase was minor (i.e., 0.4 ppbv or $5.6 \%$ ) in this study, this scheme could be applicable in future programs. Moreover, since the reactivity and concentration of VOCs influenced their $\mathrm{O}_{3}$ formation potential, the relative incremental reactivity (RIR) and RIR (weighted concentration) of LPG-related VOCs were calculated. Table 9 shows the RIR and RIR-weighted concentration of propane, propene and $n / i$-butanes. Propene had the highest RIR (i.e., $5.21 \times 10^{-2}$ ), suggesting the highest sensitivity of $\mathrm{O}_{3}$ production to propene. However, $n$-butane in LPG was found to have the highest RIR (weighted concentration) $\left(2.61 \mu \mathrm{g} \mathrm{m}^{-3}\right)$, indicating that cutting $n$-butane in LPG source was optimal for $\mathrm{O}_{3}$ pollution control. 


\section{Conclusions}

In this study, an intervention program, initiated in September 2013, and which aimed to reduce emissions of VOCs and $\mathrm{NO}_{x}$ from LPG-fueled vehicles in Hong Kong, was evaluated. The results indicated that LPG-related VOCs and $\mathrm{NO}_{x}$ decreased significantly during the program, when higher reduction rates were observed for LPG-related VOCs and $\mathrm{NO}_{x}$ compared to those in previous years. Source apportionment revealed that propane, $n / i$-butanes and NO in LPG-fueled vehicle emissions were significantly lower during than before the program. It was therefore concluded that the program was remarkably effective in reducing VOCs and $\mathrm{NO}_{x}$. To evaluate the program more comprehensively, the variation of $\mathrm{O}_{3}$ production was simulated with the PBM-MCM model. It was found that LPG-fueled vehicular emission was generally $\mathrm{O}_{3}$-destructive at the roadside $\mathrm{MK}$ site, and the $\mathrm{O}_{3}$ destruction decreased from 0.47 to $0.06 \mathrm{ppbv}$ due to the intervention program, causing an hourly average $\mathrm{O}_{3}$ increase of $0.40 \mathrm{ppbv}(\sim 5.6 \%)$. The LPG-fueled vehicle exhaust generally made negative contributions to the production of $\mathrm{OH}$ and $\mathrm{HO}_{2}$. During the program, the destructive effect weakened and even turned to a positive contribution to $\mathrm{HO}_{2}$ production, resulting in the increases of $\mathrm{OH}, \mathrm{HO}_{2}$ and $\mathrm{HO}_{2} / \mathrm{OH}$. This was in line with the fact that $\mathrm{O}_{3}$ increased slightly during the implementation of the program. To improve the program for future application, an $\mathrm{O}_{3}-\mathrm{VOCs}-\mathrm{NO}_{x}$ sensitivity analysis was conducted for ambient air that is not partitioned to sources, and the individual source of LPG-fueled vehicle exhaust. The $\mathrm{NO}_{x}$-limited regime in $\mathrm{O}_{3}$ formation was only found when $\mathrm{NO}_{x}$ was reduced to less than $5.5 \%$. Furthermore, for the emission reductions in LPG-fueled vehicle exhaust, the maximum $\mathrm{NO}_{x}$ cutting percentage of $68.9 \%$ and the lowest cutting ratio of VOCs $/ \mathrm{NO}_{x}$ (i.e., 1.1) were determined to maintain zero $\mathrm{O}_{3}$ increment.

\section{The Supplement related to this article is available online at doi:10.5194/acp-16-6609-2016-supplement.}

Acknowledgements. This study was supported by the Research Grants Council of the Hong Kong Special Administrative Region via grants PolyU5154/13E and PolyU152052/14E, and the Hong Kong Polytechnic University PhD scholarships (project no. RTUP). This study is partly supported by the Public Policy Research Funding Scheme (2013.A6.012.13A), Hong Kong PolyU internal grant (87UB) and the National Natural Science Foundation of China (no. 41275122).

Edited by: A. B. Guenther

\section{References}

Barletta, B., Meinardi, S., Simpson, I. J., Khwaja, H. A., Blake, D. R., and Rowland, F. S.: Mixing ratios of volatile organic compounds (VOCs) in the atmosphere of Karachi, Pakistan, Atmos. Environ., 36, 3429-3443, 2002.

Blake, D. R. and Rowland, F. S.: Urban Leakage of Liquefied Petroleum Gas and Its Impact on Mexico City Air Quality, Science, 269, 953-956, 1995.

Borbon, A., Locoge, N., Veilerot, M., Galloo, J. C., and Guillermo, R.: Characterization of NMHCs in a French urban atmospheric: overview of the main sources, Sci. Total Environ., 292, 177-191, 2002.

Brown, S. G., Frankel, A., and Hafner, H. R.: Source apportionment of VOCs in Los Angeles area using positive matrix factorization, Atmos. Environ., 41, 227-237, 2007.

Carter, W. L. and Atkinson, R.: Computer modeling study of incremental hydrocarbon reactivity, Environ. Sci. Tech., 23, 864-880, 1989.

Chan, C. Y. and Chan, L. Y.: Effect of meteorology and air pollutant transport on ozone episodes at a subtropical coastal Asian city, Hong Kong, J. Geophys. Res., 105, 20707-20724, 2000.

Cheng, H. R., Guo, H., Wang, X. M., Saunders, S. M., Lam, S. H. M., Jiang, F., Wang, T., Ding, A., Lee, S. C., and Ho, K. F.: On the relationship between ozone and its precursors in the Pearl River Delta: application of an observation-based model (OBM), Environ. Sci. Pollut. Res., 17, 547-560, 2010.

Chikhi, S., Boughedaoui, M., Kerbachi, R., and Joumard, R.: Onboard measurement of emissions from liquefied petroleum gas, gasoline and diesel powered passenger cars in Algeria, J. Environ. Sci., 26, 1651-1659, 2014.

Ciccone, G., Forastiere, F., Agabiti, N., Biggeri, A., Bisanti, L., Chellini, E., Corbo, G., Dell'Orco, V., Dalmasso, P., Volante, T. F., Galassi, C., Piffer, S., Renzoni, E., Rusconi, F., Sestini, P., and Viegi, G.: Road traffic and adverse respiratory effects in children, J. Occup. Environ. Med., 55, 771-778, 1998.

Farmer, D. K., Perring, A. E., Wooldridge, P. J., Blake, D. R., Baker, A., Meinardi, S., Huey, L. G., Tanner, D., Vargas, O., and Cohen, R. C.: Impact of organic nitrates on urban ozone production, Atmos. Chem. Phys., 11, 4085-4094, doi:10.5194/acp-11-40852011, 2011.

Gamas, E. D., Diaz, L., Rodriguez, R., Lopez-Salinas, E., and Schifter, I.: Exhaust emissions from gasoline- and LPG-powered vehicles operating at the altitude of Mexico city, J. Air Waste Manage., 49, 1179-1189, 1999.

Guo, H., Wang, T., and Louie, P. K. K.: Source apportionment of ambient non-methane hydrocarbons in Hong Kong: Application of a principal component analysis/absolute principal component scores (PCA/APCS) receptor model, Environ. Pollut., 129, 489498, 2004.

Guo, H., Wang, T., Blake, D. R., Simpson, I. J., Kwok, Y. H., and Li, Y. S.: Regional and local contributions to ambient non-methane volatile organic compounds at a polluted rural/coastal site in Pearl River Delta, China, Atmos. Environ., 40, 2345-2359, 2006.

Guo, H., So, K. L., Simpson, I. J., Barletta, B., Meinardi, S., and Blake, D. R.: $\mathrm{C}_{1}-\mathrm{C}_{8}$ volatile organic compounds in the atmosphere of Hong Kong: Overview of atmospheric processing and source apportionment, Atmos. Environ., 41, 1456-1472, 2007.

Guo, H., Jiang, F., Cheng, H. R., Simpson, I. J., Wang, X. M., Ding, A. J., Wang, T. J., Saunders, S. M., Wang, T., Lam, S. H. M., 
Blake, D. R., Zhang, Y. L., and Xie, M.: Concurrent observations of air pollutants at two sites in the Pearl River Delta and the implication of regional transport, Atmos. Chem. Phys., 9, 73437360, doi:10.5194/acp-9-7343-2009, 2009.

Guo, H., Cheng, H. R., Ling, Z. H., Louie, P. K. K., and Ayoko, G. A.: Which emission sources are responsible for the volatile organic compounds in the atmosphere of Pearl River Delta?, J. Hazard. Mater., 188, 116-124, 2011a.

Guo, H., Zou, S.C ., Tsai, W. Y., Chan, L. Y., and Blake, D. R.: Emission characteristics of non-methane hydrocarbons from private cars and taxis at different driving speeds in Hong Kong, Atmos. Environ., 45, 2711-2721, 2011b.

HKCSD (Hong Kong Census and Statistics Department): Hong Kong Energy Statistics: Annual Report, available at: http://www. censtatd.gov.hk (last access: 15 March 2016), 2010.

HKEPD (Hong Kong Environmental Protection Department): Air quality in Hong Kong 2013, available at: http://www.aqhi.gov.hk/en/download/air-quality-reportse469. html?showall=_\&start=_1) (last access: 15 March 2016), 2014.

Ho, K. F., Lee, S. C., Guo, H., and Tsai, W. Y.: Seasonal and diurnal variations of volatile organic compounds (VOCs) in the atmosphere of Hong Kong, Sci. Total Environ., 322, 155-166, 2004.

Ho, K. F., Lee, S. C., Cao, J. J., Chow J. C., Watson, J. G., and Chan, C. K.: Seasonal variations and mass closure analysis of particulate matter in Hong Kong, Sci. Total Environ., 355, 276$287,2006$.

Ho, K. F., Lee, S. C., Ho, W. K., Blake, D. R., Cheng, Y., Li, Y. S., Ho, S. S. H., Fung, K., Louie, P. K. K., and Park, D.: Vehicular emission of volatile organic compounds (VOCs) from a tunnel study in Hong Kong, Atmos. Chem. Phys., 9, 7491-7504, doi:10.5194/acp-9-7491-2009, 2009.

Huang, J. P., Fung, J. C. H., Lau, A. K. H., and Qin, Y.: Numerical simulation and process analysis of typhoon-related $\mathrm{O}_{3}$ episodes in Hong Kong, J. Geophys. Res., 110, D05301, doi:10.1029/2004JD004914, 2005.

Huang, J. P., Fung, J. C. H. and Lau, A. K. H.: Integrated processes analysis and systematic meteorological classification of ozone episodes in Hong Kong, J. Geophys. Res., 111, D20309, doi:10.1029/2005JD007012, 2006.

Jiang, F., Wang, T. J., Wang, T. T., Xie, M., and Zhao, H.: Numerical modeling of a continuous photochemical pollution episode in Hong Kong using QRF-chem, Atmos. Environ., 42, 8717-8727, 2008.

Lai, C. H., Chang, C. C., Wang, C. H., Shao, M., Zhang, Y. H., and Wang, J. L.: Emissions of liquefied petroleum gas (LPG) from motor vehicles, Atmos. Environ., 43, 1456-1463, 2009.

Lam, K. S., Wang, T. J., Wu, C. L., and Li, Y. S.: Study on an ozone episode in hot season in Hong Kong and transboundary air pollution over Pearl River Delta region of China, Atmos. Environ., 39, 1967-1977, 2005.

Lam, S. H. M., Saunders, S. M., Guo, H., Ling, Z. H., Jiang, F., Wang, X. M., and Wang, T. J.: Modelling VOC source impacts on high ozone episode days observed at a mountain summit in Hong Kong under the influence of mountain-valley breezes, Atmos. Environ., 81, 166-176, 2013.

Lau, A. K. H., Yuan, Z. B., Yu, J. Z., and Louie, P. K. K.: Source apportionment of ambient volatile organic compounds in Hong Kong, Sci. Total Environ., 408, 4138-4149, 2010.
Lau, J., Hung, W. T., and Cheung, C. S.: On-board gaseous emissions of LPG taxis and estimation of taxi fleet emissions, Sci. Total Environ., 409, 5292-5300, 2011.

Lee, E., Chan, C. K., and Paatero, P.: Application of positive matrix factorization in source apportionment of particulate pollutants in Hong Kong, Atmos. Environ., 33, 3201-3212, 1999.

Lee, S. C., Chiu, M. Y., Ho, K. F., Zou, S. C., and Wang, X. M.: Volatile organic compounds (VOCs) in urban atmosphere of Hong Kong, Chemosphere, 48, 375-382, 2002.

Ling, Z. H. and Guo, H.: Contribution of VOC sources to photochemical ozone formation and its control policy implication in Hong Kong, Environ. Sci. Policy, 38, 180-191, 2014.

Ling, Z. H., Guo, H., Cheng, H. R., and Yu, Y. F.: Sources of ambient volatile organic compounds and their contributions to photochemical ozone formation at a site in the Pearl River Delta, southern China, Environ. Pollut., 159, 2310-2319, 2011.

Ling, Z. H., Guo, H., Zheng, J. Y., Louie, P. K. K., Cheng, H. R., Jiang, F., Cheung, K., Wong, L. C., and Feng, X. Q.: Establishing a conceptual model for photochemical ozone pollution in subtropical Hong Kong, Atmos. Environ., 76, 208-220, 2013.

Ling, Z. H., Guo, H., Lam, S. H. M., Saunders, S. M., and Wang, T.: Atmospheric photochemical reactivity and ozone production at two sites in Hong Kong: Application of a Master Chemical Mechanism-photochemical box model, J. Geophys. Res. Atmos., 119, 10567-10582, doi:10.1002/2014JD021794, 2014.

Liu, Y., Shao, M., Lu, S. H., Chang, C. C., Wang, J. L., and Fu, L. L.: Source apportionment of ambient volatile organic compounds in the Pearl River Delta, China: Part II, Atmos. Environ., 42, 62616274, 2008.

Lou, S., Holland, F., Rohrer, F., Lu, K., Bohn, B., Brauers, T., Chang, C. C., Fuchs, H., Häseler, R., Kita, K., Kondo, Y., Li, X., Shao, M., Zeng, L., Wahner, A., Zhang, Y., Wang, W., and Hofzumahaus, A.: Atmospheric $\mathrm{OH}$ reactivities in the Pearl River Delta - China in summer 2006: measurement and model results, Atmos. Chem. Phys., 10, 11243-11260, doi:10.5194/acp-10-11243-2010, 2010.

Lu, K. D., Rohrer, F., Holland, F., Fuchs, H., Bohn, B., Brauers, T., Chang, C. C., Häseler, R., Hu, M., Kita, K., Kondo, Y., Li, X., Lou, S. R., Nehr, S., Shao, M., Zeng, L. M., Wahner, A., Zhang, Y. H., and Hofzumahaus, A.: Observation and modelling of $\mathrm{OH}$ and $\mathrm{HO}_{2}$ concentrations in the Pearl River Delta 2006: a missing $\mathrm{OH}$ source in a VOC rich atmosphere, Atmos. Chem. Phys., 12, 1541-1569, doi:10.5194/acp-12-1541-2012, 2012.

Madronich, S. and Flocke, S.: Theoretical estimation of biologically effective UV radiation at the Earth's surface, in: Solar Ultraviolet Radiation-Modeling, Measurements and Effects, edited by: Zerefos, C., NATO ASI Series, vol. I52. Springer-Verlag, Berlin, 1997.

Martien, P. T., Harley, R. A., Milford, J. B., and Russell, A. G.: Evaluation of incremental reactivity and its uncertainty in Southern California, Environ. Sci. Technol., 37, 1598-1608, 2003.

Myung, C. L., Kim, J., Choi, K., Hwang, I. G., and Park, S.: Comparative study of engine control strategies for particulate emissions from direct injection light-duty vehicle fueled with gasoline and liquid phase liquefied petroleum gas (LPG), Fuel, 94, 348-355, 2012.

Ou, J. M., Guo, H., Zheng, J. Y., Cheung, K., Louie, P. K. K., Ling, Z. H., and Wang, D. W.: Concentrations and sources of nonmethane hydrocarbons (NMHCs) from 2005 to 2013 in Hong 
Kong: A multi-year real-time data analysis, Atmos. Environ., 103, 196-206, 2015.

Paatero, P.: Least squares formulation of robust non-negative factor analysis, Chemom. Intell. Lab. Sys., 37, 23-35, 1997.

Paatero, P. and Tapper, U.: Positive matrix factorization: A nonnegative factor model with optimal utilization of error estimates of data values, Environmetrics, 5, 111-126, 1994.

Ren, X. R., Harder, H., Martinez, M., Lesher, R. L., Oliger, A., Simpas, J. B., Brune, W. H., Schwab, J. J., Demerjian, K. L., He, Y., Zhou, X. L., and Gao, H. L.: $\mathrm{OH}$ and $\mathrm{HO}_{2}$ chemistry in the urban atmosphere of New York City, Atmos. Environ., 37, 3639-3651, 2003.

Ruellan, S. and Cachier, H.: Characterisation of fresh particulate vehicular exhausts near a Paris high flow road, Atmos. Environ., 35, 453-468, 2001.

Schifter, I., Diaz, L., Lopez-Salinas, E., Rodriguez, R., Avalos, S., and Guerrero, V.: An evaluation of the LPG vehicles program in the metropolitan area of Mexico city, J. Air Waste Manage., 50, 301-309, 2000.

So, K. L. and Wang, T.: On the local and regional influence on ground-level ozone concentrations in Hong Kong, Environ. Pollut., 123, 307-317, 2003.
Takekawa, H., Chatani, S., and Akiyoshi, I.: A new approach for estimation of the effect of $\mathrm{NO}_{x}$ emission reduction on roadside $\mathrm{NO}_{2}$ concentration in Tokyo, Atmos. Environ., 68, 92-102, 2013.

Wang, T., Guo, H., Blake, D. R., Kwok, Y. H., Simpson, I. J., and Li, Y. S.: Measurements of trace gases in the inflow of South China Sea background air and outflow of regional pollution at Tai O, southern China, J. Atmos. Chem. 52, 295-317, 2005.

Wang, T., Wei, X. L., Ding, A. J., Poon, C. N., Lam, K. S., Li, Y. S., Chan, L. Y., and Anson, M.: Increasing surface ozone concentrations in the background atmosphere of Southern China, 19942007, Atmos. Chem. Phys., 9, 6217-6227, doi:10.5194/acp-96217-2009, 2009.

Wang, T. J., Lam, K. S., Xie, M., Wang, X. M., Carmichael, G., and Li, Y. S.: Integrated studies of a photochemical smog episode in Hong Kong and regional transport in the Pearl River Delta of China, Tellus B, 58, 31-40, 2006.

Xie, S. D., Zhang, Y. H., Li, Q., and Tang, X. Y.: Spatial distribution of traffic-related pollutant concentrations in street canyons, Atmos. Environ., 37, 3213-3224, 2003.

Zhang, J., Wang, T., Chameides, W. L., Cardelino, C., Kwok, J., Blake, D. R., Ding, A., and So, K. L.: Ozone production and hydrocarbon reactivity in Hong Kong, Southern China, Atmos. Chem. Phys., 7, 557-573, doi:10.5194/acp-7-557-2007, 2007. 